\title{
Lipid Rafts, Pseudotyping, and Virus-Like Particles: Relevance of a Novel, Configurable, and Modular Antigen-Presenting Platform
}

\author{
Hans J. Kueng ${ }^{a}$ Klaus G. Schmetterer ${ }^{a} \quad$ Winfried F. Pickl ${ }^{a}$ b \\ a Institute of Immunology, Center for Pathophysiology, Infectiology and Immunology, Medical University of \\ Vienna, and ${ }^{\mathrm{b}}$ Christian Doppler Laboratory for Immunomodulation, Vienna, Austria
}

\section{Key Words}

Antigen presentation - Virus-like particles • Lipid rafts ·

Pseudotyping

\begin{abstract}
Antigen presentation by professional antigen-presenting cells (APC) is the first step towards the initiation of an adaptive immune response carried out by naïve $T$ lymphocytes. For this purpose, antigens are presented in the form of peptide/major histocompatibility complexes (pMHC) on APC to the antigen receptor of $\mathrm{T}$ cells. For sustained $\mathrm{T}$ cell activation to occur, numerous additional molecules specifically expressed on the surface of APC have to synergize with pMHC to stimulate a given T lymphocyte. Moreover, soluble factors such as cytokines critically contribute to the specific milieu during T cell activation. APC 'talk' to T cells only when they engage in intimate physical interaction. The cell biological correlate of this APC-T cell interaction is commonly referred to as the formation of an immunological synapse. In this review we aim to provide an overview of a novel cell-free antigen-presenting platform, i.e. virus-like particles (VLP) decorated with immune receptors of choice, which was devised to overcome the molecular and cell biological complexity of the APC side of the immunological synapse. In the past we have demonstrated that immune receptor-decorated VLP are able to activate, modulate, or abrogate antigen-specific
\end{abstract}

T lymphocyte responses. Thus, antigen-specific VLP represent a valuable tool which might help to explore and understand the function of antigen-specific $T$ lymphocytes in more detail and might thus open new avenues for the modulation of pathologic T lymphocyte responses, e.g. for the treatment of allergic diseases.

Copyright $\odot 2010$ S. Karger AG, Basel

\section{Introduction}

Immunity is maintained by the proper function and interaction of the innate and adaptive immune systems [1]. The innate immune system controls the induction of adaptive immune responses by opsonization, uptake, processing, presentation, and transport of antigens and by regulating the provision of cosignals for lymphocyte activation. It furthermore instructs lymphocytes to develop particular effector responses by releasing key cytokines [2]. The initial transfer of information towards lymphocytes is governed by professional antigen-presenting cells (APC), i.e. dendritic cells (DC) [3]. DC are particularly important to prime major histocompatibility complex (MHC) class II-restricted CD4+ T helper cells [4] as well as MHC class I-restricted CD8+ cytotoxic T cells [5]. $\mathrm{T}$ lymphocytes which have been instructed by DC play a pivotal role especially during recall responses against

\section{KARGER}

Fax +41613061234 E-Mail karger@karger.ch www.karger.com
(C) 2010 S. Karger AG, Basel

$1018-2438 / 11 / 1542-0089 \$ 38.00 / 0$

Accessible online at:

www.karger.com/iaa
Correspondence to: Prof. Winfried F. Pickl

Institute of Immunology, Center for Pathophysiology

Infectiology and Immunology, Medical University of Vienna

Borschkegasse 8A, AT-1090 Vienna (Austria)

Tel. +43 14277 64945, Fax +43 14277 9649, E-Mail winfried.pickl@meduniwien.ac.at 
pathogenic microorganisms and malignancies [6-10]; however, they are also the driving force in autoimmune disorders $[11,12]$ and allergic diseases [13].

Over the last 15 years, a multitude of protocols for the ex vivo generation and expansion of professional APC have been established [14-17] and immunotherapies based on DC have been developed as promising tools to fight infectious diseases and cancer $[18,19]$. However, the high number of molecular interactions identified between APC and T cells makes the functional net effect of DC as T cell stimulants not easy to predict and direct [20-22]. Moreover, the limited availability of autologous DC as well as the time-consuming and cost-intensive maturation and differentiation processes required to generate high numbers of DC are additional points to be considered when planning to use DC to modulate T cell function for therapeutic purposes.

For these reasons, and to the benefit of both basic and applied research, we have developed an inducible and reductionist antigen-presenting platform for the modulation of Tlymphocyte function which is based on a natural assembly system, i.e. virus-like particles (VLP). We aimed to keep the variables low while still creating a fully functional and modular $\mathrm{T}$ cell stimulatory unit consisting of a flexible composition of T cell receptor (TCR) ligands, costimulatory and adhesion molecules, as well as cytokines, all displayed within a physiological plasma membrane context.

The objective of this review is to describe the cell and molecular biological principles on which this novel platform is built as well as the spectrum of possible applications of the platform to induce, modulate, or abrogate defined $\mathrm{T}$ cell-driven immune responses.

\section{The Immunological Synapse - A Link between Innate and Adaptive Immune Systems}

The immunological synapse formed between APC and $\mathrm{T}$ lymphocytes translates information about endogenous and foreign protein antigens to the adaptive immune system. Three categories of signals are considered to be important for optimal $\mathrm{T}$ cell activation. The first and most central interaction, 'signal 1', is initiated upon TCR binding to the peptide/MHC complex (pMHC) [23, 24], which defines the antigen specificity of the immune response [25-27]. Costimulatory signals may be delivered via cell-to-cell interaction, referred to as 'signal 2', or alternatively via soluble factors such as cytokines and growth factors collectively called 'signal 3' [28].
Specific subdomains of the plasma membrane, known as lipid rafts, are considered to play a crucial role during the sorting of molecules contributing to the formation of the immunological synapse [29-32]. In fact, the efficiency of antigen presentation is greatly improved by the enrichment of MHC molecules in lipid rafts of APC [33]. Likewise, upon binding to PMHC, the TCR and its coreceptors become concentrated in lipid rafts eventually leading to the formation of a supramolecular activation cluster [34]. When the number of engaged TCRs binding to $\mathrm{pMHC}$ reach a certain threshold, within a given period of time $\mathrm{T}$ lymphocyte signaling and activation will occur [35].

Costimulatory signals play essential roles during $\mathrm{T}$ lymphocyte activation. In fact, molecular interactions between CD80/CD28, CD86/CD28, CD58/CD2, OX40L/OX40 (CD252/CD134), and ICOS-L/ICOS (CD275/ $\mathrm{CD} 278$ ) have been demonstrated to provide activating $\mathrm{T}$ cell signals [36-39]. They either enhance the activation state of T cells by amplifying TCR signals themselves or by reducing the threshold for $\mathrm{T}$ cell activation [40]. The output of such cosignals is increased cell survival, proliferation, and/or differentiation towards effector cells [41, 42]. Another set of costimulators delivers inhibitory $\mathrm{T}$ cell signals; CD80/CTLA-4, CD86/CTLA-4, PD-L1/PD1, and PD-L2/PD-1 usually inhibit T lymphocyte activation and thereby dampen ongoing immune responses [43-45]. In the complete absence of costimulation T lymphocytes usually enter into an anergic/tolerogenic state by default $[46,47]$.

Beside the cell contact-dependent signals 1 and 2, T lymphocyte activation is also modulated by soluble factors, i.e. cytokines (signal 3), that in many instances serve as 'danger signals' in response to a large group of microbial, viral, and other stimuli as well [28, 48]. Interleukin (IL)-12 and type I interferons seem to be of particular importance for $\mathrm{CD} 8+\mathrm{T}$ lymphocyte activation and proliferation, while proinflammatory cytokines such as tumor necrosis factor- $\alpha$ and IL-1 are more potent stimulatory factors for CD4+ T lymphocytes [28, 48-51]. Growth factors such as IL-2, IL-4, IL-7, and IL-15 contribute to T cell survival and proliferation [52-55]. In contrast, IL-10 and TGF- $\beta$ direct $T$ cells rather towards antigen nonresponsiveness and tolerance [56-58]. However, in the complex network of interactions, cytokines may have opposing functions. In particular, IL-2 contributes to the regulation of the immune response, both through promoting $\mathrm{T}$ lymphocyte proliferation and by sensitizing $\mathrm{T}$ cells for programmed cell death $[59,60]$. The presence of IL- 4 at the time of antigen presentation to $\mathrm{T}$ lymphocytes is crit- 
ical for the development of Thelper 2 (Th2) lymphocytes, and IL-4 - the major inducer of class switch recombination towards $\varepsilon$-immunoglobulin heavy chains in $\mathrm{B}$ cells - as well as the eosinophil-activating cytokines IL-5 and IL-13 which are characteristic products of such Th2 cell responses $[61,62]$. In contrast, IL-12, TGF- $\beta$, and IFN- $\gamma$ negatively regulate Th2 development, instead favoring the development of $\mathrm{T}$ cells with a Th1 phenotype [63-66]. In the past, coadministration of cytokines had been considered a valuable strategy to overcome nonresponsiveness to vaccination in immunodeficient patients and to enhance antitumor immunity [67-71]. In these applications cytokines resemble adjuvants, i.e. 'helper substances' [72, 73]. Thus, besides molecularly defined ligands for TCRs and accessory molecules a novel antigen-presenting platform should ideally also be apt to accommodate cytokines and growth factors known to have an impact on T lymphocyte function.

\section{Virus-Like Particles: A Novel, Modular, and Reductionist Antigen-Presenting Platform}

In this report we review a novel technology for the facile preparation of antigen-presenting platforms, i.e. VLP, that show high functional activity. Since VLP production uses some salient features of the assembly and budding processes of enveloped viruses, we will first discuss the mechanisms operative during lipid raft formation; secondly, we will refer to the attachment of proteins by GPI (glycosyl phosphatidyl inositol) anchoring to the plasma membrane, and thirdly, we will discuss the pseudotyping of VLP in more detail.

\section{Lipid Rafts - A Plasma Membrane Sorting \\ Compartment}

It is well established that many enveloped viruses preferentially bud from plasma membrane microdomains of infected cells known as lipid rafts [74-81]. A similar budding behavior is observed with VLP, i.e. particles lacking viral nucleic acids and fusogenic envelope proteins. Lipid rafts are hydrophobic, detergent-insoluble, glycosphingolipid-enriched domains which accumulate cholesterol, sphingolipids, and gangliosides [82]. Their mobility allows them to act as mobile platforms that carry specific proteins from the trans-Golgi network to the cell surface and back to the internal membranes [83, 84]. Cholesterol depletion or the inhibition of glycosphingolipid synthesis blocks the formation of lipid rafts [85-87]. Isopycnic density gradient centrifugation in the nonionic detergent Tri- ton X-100 allows the purification of the insoluble lipid rafts from whole plasma membrane preparations at low temperatures [88]. Due to the physical properties of their major constituents, lipid rafts are structurally highly ordered $[89,90]$, attracting only proteins with 'favorable' transmembrane sequences and/or those undergoing distinct posttranslational lipid modifications such as glycosyl phosphatidyl inositol (GPI) anchor attachment [9193] or fatty-acid acylation [94-97]. Reciprocally, the composition, spatial dimensions, and half-lives of lipid rafts are influenced by lipid raft-resident proteins [98-100]. Overall, lipid rafts have been considered highly dynamic membrane substructures with short half-lives and small dimensions ranging from 5 to $20 \mathrm{~nm}$ [101-104]. In functional terms, lipid rafts have several physiological roles: (i) the sorting of membranes and associated proteins [105-107], (ii) the bidirectional intracellular trafficking of molecules to and from the eukaryotic plasma membrane [108-111], and (iii) the compartmentalization of cell surface and associated intracellular signaling molecules to enable signal transduction across the plasma membrane [112-115].

\section{GPI-Anchored Membrane Proteins}

GPI-anchored proteins are involved in a broad range of physiological processes and have diverse functions. Some of these proteins have enzymatic activity, e.g. placental alkaline phosphatase [116], acetylcholinesterase [117] or dipeptidase [118]. Others such as LFA-3 (CD58) [119] or Campath-1 (CD52) [120] influence intercellular interactions. Still others have been identified as ligandbinding receptors, e.g. LPS receptor (CD14) [121], folate receptor [122], and FcyRIII (CD16b) [123], or have been shown to regulate the complement activation cascade, e.g. decay-accelerating factor CD55 [117] or CD59 [124] (table 1). Previous studies have demonstrated that the genetic introduction of GPI anchor acceptor sequences at the C-terminus of a previously non-GPI-anchored protein efficiently targets the modified molecule into the lipid rafts of the plasma membrane [91, 125, 126]. Another type of lipid modification that targets proteins into lipid rafts is fatty acid acylation, which attaches either myristic acid to an $\mathrm{N}$-terminal glycine or palmitic acid to cysteine residues. The prominent coreceptors CD4 and CD8 as well as a number of Src-related tyrosine kinases such as Lck or Fyn become fatty acid acylated and selectively sequestered into rafts to promote cellular signal transduction (table 1) [94-96, 127-133]. Hence, in our work the genetic introduction of GPI anchor acceptor sequences at the C-terminal ends of the ectodomains of previously 
Table 1. Factors that favor the partitioning of proteins into lipid rafts

\begin{tabular}{|c|c|c|c|}
\hline Modification & Chemical bond & Examples of proteins of immune cells & Reference No. \\
\hline Myristoylation & $\begin{array}{l}\text { Covalent amid bond on N-terminal } \\
\text { glycine }\end{array}$ & $\begin{array}{l}\text { Src-related tyrosine kinases, Lck, Fyn, } \\
\text { [HIV Pr55 Gag (Gag)] }\end{array}$ & $74,127,269-271$ \\
\hline Palmitoylation & $\begin{array}{l}\text { Covalent bond; acyl-thioester linkage on } \\
\text { cysteins (S-acylation) }\end{array}$ & $\begin{array}{l}\text { CD4, CD8, CD9, CD44, CD95 (Fas, APO-1), } \\
\text { Lck, Fyn, LAT, trimeric G proteins, caveolin-3, } \\
\text { [influenza (HA), MoMLV (Env)] }\end{array}$ & $\begin{array}{l}127,129,130 \\
272-278\end{array}$ \\
\hline GPI linkage & $\begin{array}{l}\text { Covalent bond; C-terminal } \\
\text { phosphoethanolamine bridge }\end{array}$ & $\begin{array}{l}\text { CD14, CD16b, CD 37, CD } 48, \text { CD } 52, \text { CD } 53 \text {, } \\
\text { CD 55, CD 58, CD59 (and many others) }\end{array}$ & $\begin{array}{l}30,120,124 \\
279-284\end{array}$ \\
\hline Attachment of cholesterol & $\begin{array}{l}\text { Covalent bond; esterification on C-termi- } \\
\text { nal glycine after internal protein cleavage }\end{array}$ & Hedgehog protein (Hh) & $285-288$ \\
\hline Interaction with scaffolding proteins & Noncovalent protein-protein interactions & Caveolins, flotillin, Fc $\gamma$ RI (CD64) & $289-292$ \\
\hline $\begin{array}{l}\text { Cholesterol recognition/interaction } \\
\text { with amino acid consensus sequence } \\
\text { (CRAC) }\end{array}$ & $\begin{array}{l}\text { Noncovalent cholesterol-protein assembly; } \\
\text { LWYIK sequence }\end{array}$ & $\begin{array}{l}\text { Flotillin-1, flotillin-2, caveolin-1, caveolin-2, } \\
\text { peripheral-type benzodiazepine receptor (PBR), } \\
\text { HIV gp41 }\end{array}$ & $293-296$ \\
\hline
\end{tabular}

non-GPI-anchored proteins can efficiently target the immunomodulatory molecules of choice into the lipid rafts of the plasma membrane [134-138].

\section{Lipid Rafts Are Pivotal Membrane Compartments}

for the Assembly of Enveloped Viruses and the Site of

Viral Pseudotyping

The biology of many enveloped viruses is closely associated with lipid raft biology. In fact, several enveloped RNA and DNA viruses use lipid rafts as a matrix for their assembly and/or budding, even though the exact mechanisms responsible for budding and vesiculation remain a matter of speculation [139]. There is a consensus, however, that during the release of enveloped viruses from host cells viral core and surface glycoproteins become enriched in lipid rafts $[79,140,141]$. Consequently, the specific lipid composition of viruses can differ considerably from that of the respective host cells [142]. Enveloped viruses currently known to use lipid rafts for their assembly and/or budding are listed in table 2 .

Experimental VLP production has mostly relied on the Gag protein, which is the major structural protein of Retroviridae. The Gag protein contains 3 conserved regions with distinct functions: (i) the matrix protein (MA) [143], (ii) the capsid protein [144], and (iii) the nucleic acid-binding nucleocapsid protein [145]. Significantly, Gag assembles even in the absence of any other viral factor in the lipid raft regions of transduced cells and leads to the budding of noninfectious VLP [146]. Lipid raft association is primarily achieved by myristoylation of the $\mathrm{N}$-terminal glycine residue of the MA subunit within Gag pre- cursors (Pr55 Gag and Pr65 Gag) and becomes stabilized by subsequent Gag-Gag interactions [147, 148]. Consequently, the replacement of the myristic acid attachment site of MA results in a loss of association of Gag with lipid rafts associated with a loss of function $[149,150]$. Moreover, recent studies have suggested a critical role for Gag $\mathrm{L}$ domains interacting with cellular factors during the assembly and budding processes [151]. Additional cleavage products arising from the regions between the MA and the capsid protein, e.g. the p12 domain of Moloney murine leukemia virus (MoMLV), are generally believed to facilitate virus budding $[152,153]$. In addition to the direct budding from the plasma membrane, retroviruses have been shown to bud into late endosomal compartments such as multivesicular bodies (MVB) by recruiting cellular factors from the endosomal sorting complexes required for transport [154-157]. Thus, retroviruses have developed several elaborate mechanisms for exiting from their host cells, which in fact has dramatic consequences on their molecular composition and function.

Along those lines, it was first described in the early 1970s that the coinfection of a host cell by 2 unrelated enveloped viruses can lead to the formation of virus particles that contain the genome of one virus packaged within the envelope proteins of the other or both viruses. These chimeric viral particles were named pseudotypes $[158,159]$. The subsequent observation that ubiquitously expressed, lipid raft-targeted molecules such as GPI-anchored proteins, e.g. CD55 and CD59, the coreceptor CD4, Src-related tyrosine kinases but also antigen-presenting human leukocyte antigen (HLA)-DR molecules, 
Table 2. Enveloped viruses budding from lipid raft-containing membrane regions

\begin{tabular}{|c|c|c|c|c|c|}
\hline Virus & Family & $\begin{array}{l}\text { Proteins involved in } \\
\text { VLP forming }\end{array}$ & $\begin{array}{l}\text { Raft association of viral proteins } \\
\text { demonstrated by }\end{array}$ & Authors & Reference No. \\
\hline \multicolumn{6}{|c|}{ Negative-sense ssRNA viruses } \\
\hline $\begin{array}{l}\text { Newcastle disease } \\
\text { virus (NDV) }\end{array}$ & Paramyxoviridae & $\begin{array}{l}\text { Matrix protein }(\mathrm{M}) \\
\text { Hemagglutinin- } \\
\text { neuraminindase } \\
(\mathrm{HN})\end{array}$ & $\begin{array}{l}\text { Cholesterol depletion (cyclodextrin) } \\
\text { Detergent resistance (Triton X-100) } \\
\text { Incorporation of raft-associated } \\
\text { proteins into virions (e.g. Caveolin-1) } \\
\text { Exclusion of nonraft associated } \\
\text { proteins from virions (e.g. CD71) }\end{array}$ & $\begin{array}{l}\text { Takimoto and Portner, 2004; } \\
\text { Laliberte et al., 2006; Pantua et } \\
\text { al., 2006; Shnyrova et al., } 2007\end{array}$ & $76,297-299$ \\
\hline $\begin{array}{l}\text { Respiratory } \\
\text { syncytial virus } \\
\text { (RSV) }\end{array}$ & Paramyxoviridae & $\begin{array}{l}\text { Fusion protein }(\mathrm{F}) \\
\text { Matrix protein }(\mathrm{M})\end{array}$ & $\begin{array}{l}\text { Detergent resistance (Triton X-100) } \\
\text { Colocalization with CD } 44 \text {, Caveolin-1 } \text { DiIC }_{16}(3) \\
\text { Electron microscopy } \\
\text { Confocal microscopy (GM1 staining) }\end{array}$ & $\begin{array}{l}\text { McCurdy et al., 2003; Marty } \\
\text { et al., 2004; Takimoto and } \\
\text { Portner, 2004; Fleming et al., } \\
\text { 2006; Oomens et al., 2006; } \\
\text { Batonick et al., } 2008\end{array}$ & $297,300-304$ \\
\hline $\begin{array}{l}\text { Measles virus } \\
(\mathrm{MV})\end{array}$ & Paramyxoviridae & $\begin{array}{l}\text { Matrix protein }(\mathrm{M}) \\
\text { Fusion protein }(\mathrm{F})\end{array}$ & Detergent resistance (Triton X-100) & $\begin{array}{l}\text { Manie et al., 2000; } \\
\text { Takimoto and Portner, 2004; } \\
\text { Pohl et al., } 2007\end{array}$ & $77,297,305$ \\
\hline $\begin{array}{l}\text { Sendai virus } \\
(\mathrm{SeV})\end{array}$ & Paramyxoviridae & $\begin{array}{l}\text { Matrix protein }(\mathrm{M}) \\
\text { Fusion protein }(\mathrm{F})\end{array}$ & Detergent resistance (Triton X-100) & $\begin{array}{l}\text { Takimoto et al., 2001; Schmitt } \\
\text { et al., 2002; Gosselin-Grenet et } \\
\text { al., 2006; Irie et al., } 2008\end{array}$ & $306-309$ \\
\hline $\begin{array}{l}\text { Vesicular stoma- } \\
\text { titis virus (VSV) }\end{array}$ & Rhabdoviridae & Matrix protein (M) & Immunogold electron microscopy & $\begin{array}{l}\text { Brown et al., 2003; Irie et al., } \\
\text { 2004; Swinteck et al., } 2008\end{array}$ & $310-312$ \\
\hline $\begin{array}{l}\text { Marburg virus } \\
(\mathrm{MARV})\end{array}$ & Filoviridae & $\begin{array}{l}\text { Matrix protein } \\
(\mathrm{VP} 40)\end{array}$ & $\begin{array}{l}\text { Detergent resistance (Triton X-100) } \\
\text { Confocal microscopy (GM1 staining) }\end{array}$ & $\begin{array}{l}\text { Bavari et al., 2002; } \\
\text { Kolesnikova et al., 2004; } \\
\text { Kolesnikova et al., } 2009\end{array}$ & $313-315$ \\
\hline Ebola virus & Filoviridae & $\begin{array}{l}\text { Matrix protein } \\
(\mathrm{VP} 40)\end{array}$ & $\begin{array}{l}\text { Detergent resistance (Triton X-100) } \\
\text { Confocal microscopy (GM1 staining) }\end{array}$ & $\begin{array}{l}\text { Bavari et al., 2002; Freed, 2002; } \\
\text { Aman et al., 2003; Dolnik et al., } \\
2008\end{array}$ & $313,316-318$ \\
\hline $\begin{array}{l}\text { Influenza virus } \\
\text { type A }\end{array}$ & $\begin{array}{l}\text { Orthomyxo- } \\
\text { viridae }\end{array}$ & $\begin{array}{l}\text { Hemagglutinin (HA) } \\
\text { Neuraminidase (NA) } \\
\text { Matrix protein (M1) }\end{array}$ & $\begin{array}{l}\text { Cholesterol depletion (Cyclodextrin) } \\
\text { Detergent resistance (Triton X-100) } \\
\text { Electron microscopy } \\
\text { Dynamic light scattering }\end{array}$ & $\begin{array}{l}\text { Scheifferle et al., 1999; } \\
\text { Gomez-Puertas et al., 2000; } \\
\text { Leser et al., 2005; Chen et al., } \\
\text { 2007; Radyukhin et al., } 2008\end{array}$ & $142,319-322$ \\
\hline \multicolumn{6}{|c|}{$R N A$ reverse transcribing viruses } \\
\hline MoMLV & Retroviridae & $\begin{array}{l}\text { Group-specific } \\
\text { antigens (Gag) }\end{array}$ & $\begin{array}{l}\text { Detergent resistance (Triton X-100) } \\
\text { Electron microscopy }\end{array}$ & $\begin{array}{l}\text { Henderson et al., 1983; Rein et } \\
\text { al., 1986; Hansen et al., 1990; } \\
\text { Pickl et al., 2001; Derdak et al., } \\
\text { 2006; Kueng et al., } 2007\end{array}$ & $\begin{array}{l}79,134,135 \\
144,149,323\end{array}$ \\
\hline $\begin{array}{l}\text { Human immu- } \\
\text { nodeficiency } \\
\text { virus (HIV-1, } \\
\text { HIV-2) }\end{array}$ & Retroviridae & Pr55 Gag (Gag) & Detergent resistance (Triton X-100) & $\begin{array}{l}\text { Bryant et al., 1990; Spearman } \\
\text { et al., 1994; Zhou et al., 1994; } \\
\text { Morikawa et al., 1996; Nguyen } \\
\text { et al., 2000; Bhattacharya et al., } \\
\text { 2006; Urano et al., } 2008\end{array}$ & $\begin{array}{l}74,78,270 \\
324-327\end{array}$ \\
\hline
\end{tabular}

or the adhesion molecule ICAM-1 (CD54) were efficiently incorporated into virus particles along with viral Gag proteins allowed the formation of a first basic concept for the intentional production of noninfectious VLP decorated with lipid-modified molecules of choice [79, 160164].

In summary, 2 requirements are crucial for the successful generation of VLP as a modular antigen-present- ing platform: (i) the application of viral core proteins, which efficiently trigger VLP budding and release from lipid raft regions of producer cells, and (ii) the modification of immunomodulatory molecules of choice by sequences inducing their posttranslational lipid modification, e.g. GPI anchor attachment, leading to their concentration in lipid rafts of producer cells and the subsequent pseudotyping of emerging VLP. The specific composi- 
Table 3. Methodology of VLP production

VLP production is performed according to the following standardized protocol:

1 Semiconfluently culture and passage HEK-293 cells (American Type Culture Collection, Manassas, Va., USA) in Iscove's modified Dulbecco's medium plus $10 \%$ fetal calf serum at $37^{\circ} \mathrm{C}$ and $5 \% \mathrm{CO}_{2}$ in a humidified atmosphere.

2 Day 1: Trypsinize HEK-293 cells at $37^{\circ} \mathrm{C}$ for $5 \mathrm{~min}$, wash twice with the medium, and resuspend to obtain a single cell suspension. Seed $3 \times 10^{6}$ cells per $100-\mathrm{mm}$ dish and culture in a total volume of $13 \mathrm{ml}$ of Iscove's modified Dulbecco's medium overnight.

3 Day 2 (cell confluence should be $30-50 \%$ ): Tilt plate by $10^{\circ}$, remove the medium, and carefully add $13 \mathrm{ml}$ of fresh medium by pointing the pipette tip to the wall of the tissue culture plate, preventing the detachment of adherent cells.

4 Rest cells by incubating for at least $1 \mathrm{~h}\left(37^{\circ} \mathrm{C}, 5 \% \mathrm{CO}_{2}\right)$. Prewarm the transfection reagents to $37^{\circ} \mathrm{C}$.

5 Transfection procedure [328]: Dilute $30 \mu \mathrm{g}$ of plasmid DNA (e.g. encoding GPI-anchored T cell ligand) in $900 \mu$ l of $\mathrm{ddH}_{2} \mathrm{O}$ (including $7 \mu \mathrm{g}$ of pMD-gag-pol to induce VLP production). Add $100 \mu \mathrm{l}$ of $2.5 \mathrm{M} \mathrm{CaCl}_{2}$. While vortexing the $\mathrm{DNA} / \mathrm{CaCl}_{2}$ solution, add $1 \mathrm{ml}$ of $2 \times$ HEPES-buffered saline. Incubate the transfection mix for exactly $1 \mathrm{~min}$ at room temperature. Subsequently, use a 1-ml pipette to quickly spread the transfection mix drop-wise onto HEK-293 cells and culture overnight.

6 Day 3: Change medium as described above and culture cells for the next $48 \mathrm{~h}$.

7 Day 5: Collect the VLP-containing supernatant into a 15-ml tube. Remove cellular debris by centrifugation ( $900 \mathrm{~g}$ for $10 \mathrm{~min}$ ) and filtration $(0.45 \mu \mathrm{m})$. Use VLP directly (crude) or upon concentration/purification by ultracentrifugation $(100,000 \mathrm{~g}$ for $1 \mathrm{~h})[134,135]$.

8 Determine and adjust the protein concentration of the purified VLP.

9 Use at a concentration of $1-10 \mu \mathrm{g} / \mathrm{ml}$ for stimulation assays.

10 Store the VLP at $-80^{\circ} \mathrm{C}$ for later use [136].

tion, functional capabilities, and possible applications of such pseudotyped VLP, called 'immunosomes', 'anergosomes', and 'fluorosomes' (FS) [134-137], are shown in figure 1.

Immunosomes: Immunostimulatory VLP Decorated with Ligands for TCR and Costimulatory Molecules

The T lymphocyte stimulatory potential of VLP decorated with immunomodulatory molecules, called 'immu-
Table 4. VLP - facts and figures

\begin{tabular}{|c|c|}
\hline Yield & $9.8 \pm 4.5 \mu \mathrm{g} / \mathrm{ml}$ supernatant $[135,136]$ \\
\hline Size & $\begin{array}{l}\text { diameter of } \sim 100 \mathrm{~nm} \text { (transmission electron } \\
\text { micrography) }[134,135]\end{array}$ \\
\hline Mass & $\begin{array}{l}\text { assumed mass of } 6.5 \times 10^{7} \mathrm{Da} \text { (C-type retrovirus } \\
\text { particles) [329] }\end{array}$ \\
\hline $\begin{array}{l}\text { Targeted } \\
\text { molecules, } \mathrm{n}\end{array}$ & $8-26$ per particle $[135,136]$ \\
\hline $\begin{array}{l}\text { Biological } \\
\text { activity }\end{array}$ & $\begin{array}{l}6 \times 10^{4} \text { units of IL-2 per mg of VLP } \\
\text { (human IL-2:GPI) [135] }\end{array}$ \\
\hline Purification & $\begin{array}{l}\text { ultracentrifugation at } 100,000 \mathrm{~g} \text { for } 1 \mathrm{~h} \text {, high } \\
\text { physical stability and recovery }[134]\end{array}$ \\
\hline Stability & $\begin{array}{l}\text { stable at } 4^{\circ} \mathrm{C} \text { for up to } 4 \text { days (crude VLP), } \\
\text { stable at }-80^{\circ} \mathrm{C} \text { for prolonged periods of time, } \\
\text { i.e. }>30 \text { days (purified VLP) [136] }\end{array}$ \\
\hline Safety & noninfectious and nonrenewable [134] \\
\hline
\end{tabular}

nosomes', was first demonstrated by a polyclonal approach in vitro [134] (the method for the production of VLP is shown in table 3). For this purpose a GPI-modified surrogate TCR ligand was targeted to lipid rafts of human embryonic kidney (HEK)-293 epithelial cells to subsequently decorate VLP induced by the cotransfection of MoMLV core proteins (orginal gag-pol; OGP). For the delivery of the polyclonal signal 1 , a single-chain variable fragment $(\mathrm{scFv})$ of the OKT3 hybridoma recognizing the $\mathrm{CD} 3$ epsilon subunit of the TCR/CD3 complex was generated and fused to the GPI-anchored molecule CD14 (OKT3scFv::GPI) [165]. Similarly, and in order to also provide signal 2 for T cell activation on VLP, the costimulatory molecule CD80 as well as the intercellular adhesion molecule ICAM-1 (CD54) were modified at their C-terminus with the GPI anchor acceptor sequence of the low-affinity FcyRIII (CD16b). The colocalization of immune receptors on immunosomes was confirmed by capture enzyme-linked immunosorbent assays (ELISA). $\left[{ }^{3} \mathrm{H}\right]$-thymidine uptake experiments showed that VLP-induced T cell proliferation was strictly dependent on the coexpression of both TCR/CD3 ligands (signal 1) and costimulatory molecules (signal 2). Interestingly, immunosomes were found to be able to stimulate $\mathrm{T}$ lymphocytes in vitro directly and independently of accessory cells. This was in clear contrast to several studies performed with a related form of microvesicles, i.e. exosomes, showing that their function critically depends on cross presentation by DC $[134,166]$. In contrast to constitutively released exosomes [166], MoMLV Gag neoexpression 

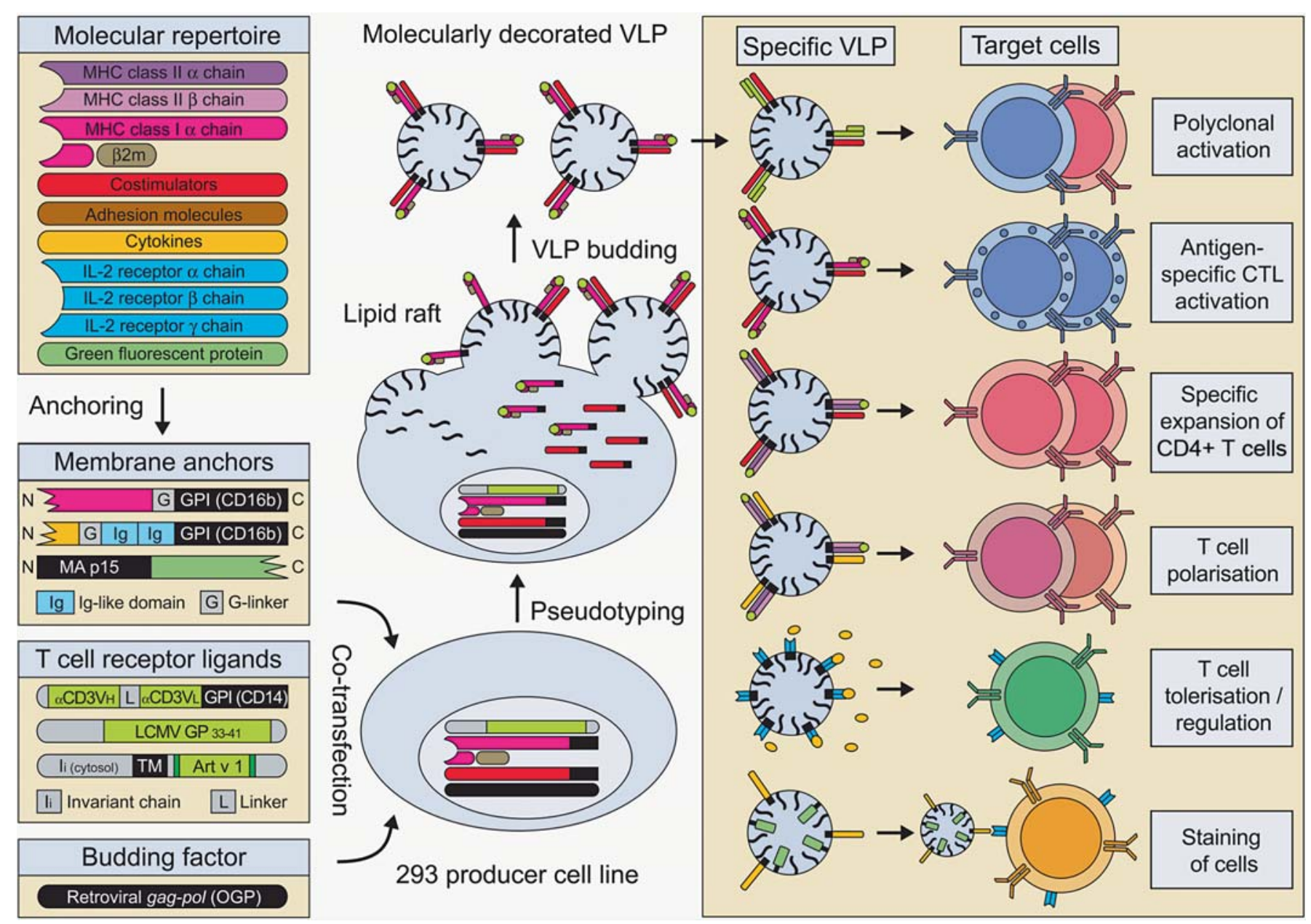

Fig. 1. Constructs, production scheme, and application of VLP decorated with molecules of choice. Coding sequences of immunomodulatory molecules were modified at their C-termini by the CD16b GPI anchor acceptor sequence in the presence or absence of 2 CD16b Ig-like domains (Ig) (left). Molecular flexibility was provided by a polyglycine linker (G). MoMLV matrix protein (MA p15) was fused to the N-terminus of green fluorescent protein. Three different systems for the provision of TCR ligands were established: (i) for polyclonal activation the variable heavy and light chains of an aCD3 antibody were linked and expressed as fusion with the GPI-anchored molecule CD14, (ii) for the antigen-specific activation of MHC class I-restricted CD8+ T cells a peptide of LCMV GP $33-41$ was employed as minigene expressed in combination with $H-2 D^{b}$ and $\beta_{2}$-microglobulin $(\beta 2 \mathrm{~m})$, and (iii) for the antigen-specific activation of MHC class II-restricted CD4+ T helper cells an Ii-based antigen delivery system was applied allowing the exchange of CLIP for model allergen peptide sequences, e.g. Art v $1_{25-34}$ of mugwort (Artemisia vulgaris). The retroviral MoMLV proteins gag-pol (OGP) were used to induce VLP budding. After transfection into HEK-293 producer cells, GPI-anchored or MA-anchored molecules of interest become expressed and targeted to lipid rafts of the plasma membrane (center). Additional coexpression of MoMLV gag-pol (OGP) induces the budding and secretion of pseudotyped plasma membrane-derived VLP. To stimulate various forms of T cells, VLP were harvested from the producer cell culture supernatants and either used directly or upon purification by ultracentrifugation. Depending on the quality of the cosignals used, VLP offer the possibility to activate and expand, anergize, or polarize antigen-specific but also polyclonal T lymphocytes (right). VLP decorated with biologically active mono- and multi-subunit immune receptors of choice (e.g. cytokine receptors) and fluorescent proteins (FS) enables the visualization, targeting, and blocking of complex immune receptor-ligand interactions. 
clearly induces de novo particle budding from the plasma membrane, as demonstrated by biochemical and functional experiments $[134,135]$ (table 4). Moreover, the molecular composition of immunosomes, in contrast to exosomes, was shown to be designable and adjustable at the level of producer cell transfection $[134,167]$ (table 4). As a consequence, the donor-dependent MHC allotypes as well as the overall molecular makeup of immunosomes are easily adjustable $[134,137]$. Nevertheless, the expression of molecules involved in antigen presentation and $\mathrm{T}$ cell activation also classifies immune cell-derived exosomes as vesicular types of immunomodulators [167].

\section{VLP Decorated with Membrane-Bound Cytokines}

Apart from classical immune receptors, VLP can also be efficiently decorated with functionally active cytokines. For that purpose, membrane-bound cytokines were generated from different species and their function compared to their soluble homologs. To that end, the GPI anchor acceptor sequence of CD16b or the transmembrane domains of type I proteins were used to construct membrane-anchored variants of cytokines [135]. In biochemical experiments and immunoelectron microscopy evaluations it became apparent that lipid raft targeting and the enrichment of cytokines on VLP were strictly dependent on the type of membrane attachment. While GPI-anchored cytokines decorated VLP, cytokines fused to transmembrane regions of type I membrane proteins did not, although the expression levels of molecules on producer cells were comparable [135].

The biological properties of the soluble growth factor IL-2 during primary and recall immune responses as well as its role in the induction of immunotolerance has been well established in the past [168-170]. Thus, IL-2 seemed to be an ideal model cytokine to test membrane-attached variants functionally and in a broader context. Significantly, dose-dependent proliferation assays revealed that the specific functional activity of GPI-anchored VLPbound human IL-2 is equal to that of its natural soluble counterpart [135]. Other GPI-anchored growth factors, such as IL-7, IL-12, and IL-15 showed a comparable, although somewhat weaker tendency to costimulate $\mathrm{T}$ cells. Another study demonstrated that the cytokines IL-4 and GM-CSF, when expressed in a GPI-anchored form on VLP, synergized to differentiate purified CD14+ monocytes towards DC similar to their soluble homologs $[15,135,171]$. These results indicated that the colocalization of more than 1 cytokine on the VLP surface does not compromise their individual functions. Nevertheless, extensive comparative studies detailing the function of
VLP-bound cytokines, e.g. as adjuvants to foster amongst others antiviral $\mathrm{T}$ and $\mathrm{B}$ cell responses, are clearly warranted in the future.

Notably, VLP can also be efficiently decorated with functionally active multimeric cytokine receptors such as the IL-2 receptor which consists of an $\alpha$-, a $\beta$-, and a $\gamma$ chain (CD25, CD122, CD132) [136]. These findings seem to be of special interest since CD25+ regulatory CD4+ T cell (nTreg) subsets have been shown to exert their regulatory function on activated effector CD4+ T cells by among other mechanisms - binding and neutralizing secreted IL-2 and other common $\gamma$-chain-(CD132)-associated cytokines [172]. In our studies, IL-2 receptor-decorated VLP not only bound but also neutralized soluble IL-2 [136]. IL-2 receptor-decorated VLP thereby displayed cytokine deprivation capabilities commonly associated with regulatory cells [136]. This may open new avenues to exploit 'regulatory' VLP for therapeutic purposes.

\section{Peptide/MHC-Decorated VLP Elicit Effector Programs} in Antigen-Specific CD8+ T Lymphocytes

In a further study, the replacement of the surrogate TCR ligand by bona fide MHC molecules was assessed by peptide loading and presentation, e.g. of viral antigens, by VLP to activate antigen-specific effector programs in CD8+ cytotoxic T lymphocytes (CTL). CTL have the specific ability to destroy pathogenic cells, such as those infected with viruses or presenting tumor antigens.

Although numerous reports demonstrated that peptide/HLA complexes might accumulate in APC lipid rafts and thus in the immunological synapse during antigen presentation $[33,173,174]$, the functionality of artificially GPI-anchored pMHC has remained a matter of controversy $[175,176]$. Since endogenous HLA class I molecules of HEK-293 cells are only weakly targeted to lipid rafts [177], immunosomes could be decorated nearly exclusively with heterologous HLA class I molecules of choice modified by GPI anchor acceptor sequences and expressed in VLP producer cells. In proof-of-principle studies, VLP decorated with the GPI-anchored murine (m) MHC molecule $\mathrm{H}-2 \mathrm{D}^{\mathrm{b}}$ along with $\mathrm{m} \beta_{2}$-microglobulin, mCD54::GPI, mCD80::GPI, and a peptide minigene coding for the immunodominant CD8+ T cell epitope of lymphocytic choriomeningitis virus glycoprotein (LCMV-GP $33-41$ ) induced a strong activation of antigenspecific T lymphocytes in vitro [134] which was comparable to bone marrow-derived (BM) DC pulsed with LCMV peptide. Furthermore, the coculture of splenocytes from P14 TCR transgenic mice specific for LCMV-GP $_{33-41}[178]$ with antigen-specific immunosomes 
induced the surface expression of CD107a (LAMP-1) on the majority of the LCMV-GP $33-41$-specific CD8+ T cell subset, which indicated cytotoxic granule exocytosis [179]. Additionally, the cell population expanded in the presence of LCMV-specific immunosomes was cytotoxic and lysed syngeneic EL4 target cells that were pulsed with LCMV-GP ${ }_{33-41}$ peptide with a high specificity [134]. Again, the cytotoxic potential of T lymphocytes (CTL) activated by immunosomes was comparable to CTL activated by BM DC and superior to BM DC pulsed with exosomes in vitro [134]. In vivo studies further corroborated the in vitro findings. In fact, upon intravenous injection $\mathrm{LCMV}_{33-41}$-specific immunosomes activated antigenspecific transgenic $\mathrm{T}$ lymphocytes as assessed by the upregulation of CD69. In those studies, a colocalized second signal on VLP was strictly required to induce T cell activation [135]. It will be interesting to explore whether and how the immune responses against whole viral envelope proteins and peptide/MHC class II complexes expressed on VLP might benefit from coexpressed membranebound cytokines displayed on VLP in future experiments.

The antigen-specific priming and activation of virusor tumor-specific CD8+ T cells could lead to the development of new strategies for the treatment of viral diseases and cancer [180-182].

\section{Peptide/MHC Class II-Decorated VLP Modulate the}

Function of Antigen-Specific CD4+ T Lymphocytes

$\mathrm{CD} 4+\mathrm{T}$ helper lymphocytes are key elements on the one hand for the optimal activation of CD8+ cytotoxic T lymphocytes [183] and on the other for the activation and provision of helper signals for B lymphocytes during antigen recognition and immunoglobulin class switching [184-186]. Interferon- $\gamma$ (IFN- $\gamma$ )-secreting Th1 cells are important for the clearance of intracellular pathogens and were shown to drive antibody-mediated responses, in particular IgG2a, but are also involved in cell-mediated immune responses leading to tissue damage [62]. In contrast, Th2 lymphocytes drive mainly IgE-mediated antibody responses and thus play a central role in the defense against helminthes and in the induction and maintenance phase of type I allergies $[13,187,188]$. Th17 cells, characterized as preferential producers of IL-17, IL-21, and IL-22, are important for the clearance of extracellular pathogens and are known to have potent proinflammatory functions $[189,190]$, while regulatory CD4+ T cell subsets, CD25+ nTregs, IL-10-producing type 1 regulatory $\mathrm{T}(\mathrm{Tr} 1)$ cells, and TGF- $\beta$-expressing $\mathrm{T}$ regulatory type $3(\mathrm{Tr} 3)$ cells play critical roles for the maintenance of immune homeostasis and peripheral tolerance to self an- tigens [191-194]. Substantial evidence suggests that these cell types also control the immune responses to allergens and transplantation antigens $[13,195,196]$.

Thus, it was thought that the antigen-specific VLPbased modulation of CD4+ Thelper lymphocytes in general and of allergen-specific $\mathrm{T}$ cells in particular might represent a promising approach to influence the undesired Th2-biased immune response to allergens. To address this question, HLA class II/allergen peptide-decorated VLP have been generated expressing the immunodominant epitope of a model allergen, i.e. Art $\mathrm{v} 1_{25-36}$, the major mugwort pollen allergen (Artemisia vulgaris), together with HLA-DRA*0101 and HLA-DRB1*0101, respectively [197-200], to deliver the allergen-specific signal 1 [138]. The loading of HLA class II molecules with Art v $1_{25-36}$ peptide was achieved by an invariant-chain (Ii)-based approach $[138,201]$ which replaces the CLIP sequence of Ii with the sequence coding for the allergen peptide. Significantly, VLP displayed transmembrane HLA class II molecules organized as $\alpha \beta$-heterodimers with expression levels comparable to related types of vesicles, i.e. exosomes derived from immortalized B cell lines. VLP expressing HLA-DR1/Art v $1_{25-36}$ complexes and coexpressing CD80::GPI induced the allergen-specific proliferation of Art v 1-specific $\mathrm{T}$ cell clones from allergic individuals and $\mathrm{PB}$ T cells from nonallergic individuals transduced with an allergen-specific TCR [138]. $\mathrm{T}$ cell activation and clonal expansion in vitro were found to be independent of accessory cells. Moreover, primary cultures of allergen-specific T lymphocytes cocultivated with VLP presenting signal 1 in the absence of costimuli, proliferated neither upon primary stimulation nor upon secondary stimulation with anti-CD3/CD28-coated microbeads. Significantly, this form of T cell unresponsiveness could be overcome by the addition of high concentrations of IL-2, indicating that the T cells were nonresponsive but still alive [137], which was perfectly in line with the functional definition of anergic cells [47, 202, 203]. However, recent reports imply increasing complexity within the field of anergic T cell phenotypes warranting further in vitro and in vivo investigations to clarify whether the VLP-induced anergy is long lasting and whether altered peptide ligand/MHC complexes would further affect anergic T cell phenotypes [204-207].

The coexpression of the CD28 ligands CD80::GPI or CD86 on allergen-specific VLPs led to the clear-cut secretion of IFN- $\gamma$, IL-2, and IL-13 [137], which is compatible with previous reports $[208,209]$. In marked contrast, CD58::GPI coexpression induced IL-10/IFN- $\gamma$-secreting T cells rendering IL-2, IL-4, and IL-13 levels low. The cy- 
tokine profile observed upon CD58 costimulation was intriguingly reminiscent of T-regulatory cells 1 (Tr1) described by Groux et al. $[192,210]$. Of the utmost clinical importance in that context are the reports describing the induction of IL-10 and/or IFN- $\gamma$-secreting T cells upon allergen-specific immunotherapy [211-213]. These findings have been further corroborated by reports demonstrating the predominance of IL-10 and/or IFN- $\gamma$-secreting $\mathrm{T}$ cells in healthy individuals without allergy. The results obtained with allergen-presenting VLPs coexpressing CD58 suggest an important role of the CD58$\mathrm{CD} 2$ signaling axis in the induction of allergen-specific IL-10/IFN- $\gamma$-secreting T cells. Similar T cell phenotypes were observed upon the triggering of $\mathrm{CD} 46$ by its natural ligands as well as upon $\mathrm{T}$ cell activation in a milieu rich in IL-27 [214, 215].

The data imply that colocalization on allergen-specific VLPs of distinct T cell ligands, either in the form of ligands for costimulatory molecules or as classical cytokines, might be a valid strategy to modulate the function of antigen-specific $\mathrm{T}$ cells in future immunotherapy protocols.

\section{Comparison of Immunomodulatory VLP to Other Antigen-Presenting Systems}

VLP represent versatile tools for the modulation of antigen-specific T lymphocytes. Thus, VLP unite several beneficial features of already established antigen-presenting and $\mathrm{T}$ cell stimulatory systems (table 5).

\section{Ligand-Decorated VLP Compared to Purified Protein}

Ligands

T lymphocytes can be stimulated by matrix-immobilized ligands or antireceptor monoclonal antibodies [88, $115,216]$. In fact, receptor aggregation by multivalent ligands represents a fundamental mechanism of immune cell activation, which has been analyzed rigorously [217222]. As described above, the VLP platform supports the display of multivalent TCR ligands in the form of pMHC complexes [134-137]. Its valency and free combination capability with costimulatory molecules of choice represents, however, a considerable advantage over T cell-stimulatory approaches using purified proteins.

\section{VLP Compared to Planar Phospholipid Membranes} and Liposomes

In the past, synthetic model membrane surfaces such as glass-supported lipid bilayers (SLB) were developed
[223]. Importantly, lipid composition in SLB can be varied and individual lipid molecules are highly mobile [224, 225]. Although molecularly well defined, their limitations should nevertheless be discussed: (i) ligand mobility on natural APC seems to be hardly reproducible by SLB, (ii) freely diffusing ligands do not support tension and may thus affect ligand clustering, and (iii) liposome preparation includes several steps that may not be compatible with fragile proteins; consequently, such proteins must be purified first and introduced upon vesicle formation or bilayer deposition [226, 227]. In contrast, VLP are direct derivatives of the plasma membrane of 'producer cells'. They represent a natural membrane makeup regarding lipid composition, morphological membrane curvatures, and ligand mobility. Moreover, VLP production is highly reproducible and requires neither the purification of the proteins to be introduced nor the eventual painting of VLP with receptors of interest [92, 228, 229]. Finally, while VLP activate T lymphocytes directly in vitro and in vivo, activation by pMHC-decorated liposomes seems to depend on additional supporting membrane surfaces [230-232].

\section{VLP Compared to Coated Magnetic Beads}

Magnetic beads coated with anti-CD3 and anti-CD28 monoclonal antibodies were used by Levine et al. [233] to efficiently expand polyclonal CD4+ T lymphocytes ex vivo and in the absence of feeder cells. Moreover, pMHC/ anti-CD28-coated magnetic beads were successfully applied to expand antigen-specific T cells ex vivo [234]. After 3 rounds of stimulation, the majority of $\mathrm{T}$ cells were found to be antigen-specific ( $>85 \%)$ which was comparable to data obtained with VLP (84\%) [137]. Despite the clear-cut potential for the ex vivo expansion of T cells, e.g. for adoptive transfer purposes, the physical composition of microbeads certainly does not allow their systemic application.

\section{VLP Compared to Exosomes}

Exosomes represent another cell-free system for antigen presentation and $\mathrm{T}$ cell activation. Exosomes are microvesicles of $60-90 \mathrm{~nm}$ in size that are contained within MVB and released into the extracellular environment upon the fusion of the MVB with the cellular plasma membrane [166]. Along with reticulocytes [235], epithelial cells [236], neurons [237], immune cells such as B and T lymphocytes [238, 239], mast cells [240], and DC [241] but also distinct tumor cells [242] have been shown to secrete exosomes. The molecular composition of exosomes is a result of their cells of origin. Exosomes are released 
Table 5. Antigen-presenting systems

\begin{tabular}{|c|c|c|c|c|c|c|}
\hline System & $\begin{array}{l}\text { Antigen } \\
\text { specificity }\end{array}$ & $\begin{array}{l}\text { Antigen } \\
\text { processing }\end{array}$ & $\begin{array}{l}\mathrm{T} \text { cell } \\
\text { expansion }\end{array}$ & $\begin{array}{l}\text { Clinical } \\
\text { application }\end{array}$ & Authors & Reference No. \\
\hline \multicolumn{7}{|c|}{ Acellular antigen-presenting systems } \\
\hline $\begin{array}{l}\text { Immobilized mono- } \\
\text { clonal antibody }\end{array}$ & no & no & +++ & yes & $\begin{array}{l}\text { Van Wauwe et al., 1980; Meuer et al., 1983; } \\
\text { Tax et al., 1984; Riddell and Greenberg, } 1990\end{array}$ & $216,330-332$ \\
\hline Coated magnetic beads & no/yes & no & +++ & yes & $\begin{array}{l}\text { Levine et al., 1997; Oelke et al., 2003; } \\
\text { Maus et al., } 2003\end{array}$ & $233,333,334$ \\
\hline Liposomes & yes & no & $+/-$ & no & $\begin{array}{l}\text { Delbrück et al., 1968; Herrmann et al., 1982; } \\
\text { Mescher, 1992; Prakker et al., } 2000\end{array}$ & $230-232,335$ \\
\hline $\begin{array}{l}\text { Supported planar } \\
\text { lipid bilayers }\end{array}$ & yes & no & $+/-$ & no & $\begin{array}{l}\text { Brian and McConell, 1984; Groves et al., 1997; } \\
\text { Grakoui et al., 1999; Groves et al., 2003; } \\
\text { Mossman et al., } 2005\end{array}$ & $\begin{array}{l}219,222, \\
224,336,337\end{array}$ \\
\hline Exosomes & yes & yes & $++/-$ & yes & $\begin{array}{l}\text { Raposo et al., 1996; Zitvogel et al., 1998; } \\
\text { Vincent-Schneider et al., 2002; Segura et al., 2005; } \\
\text { Admyre et al., 2007; Viaud et al., } 2009\end{array}$ & $\begin{array}{l}238,241 \\
245,247 \\
249,338\end{array}$ \\
\hline Tolerogenic exosomes & yes & yes & - & no & Kim et al., 2005; Bianco et al., 2009 & 265,266 \\
\hline Painted viral particles & no & no & - & no & Metzner et al., 2008 & 339 \\
\hline Immunosomes (VLP) & yes & yes & +++ & no & $\begin{array}{l}\text { Derdak et al., 2006; Kueng et al., 2007; } \\
\text { Leb et al., } 2009\end{array}$ & $134,135,137$ \\
\hline $\begin{array}{l}\text { Anergosomes } \\
\text { (tolergenic VLP) }\end{array}$ & yes & yes & - & no & Leb et al., 2009; Kueng et al., 2010 & 136,137 \\
\hline \multicolumn{7}{|c|}{ Cellular antigen-presenting systems } \\
\hline Autologous 'feeder' cells & yes & no & +++ & yes & Dudley et al., 2002, 2003, 2005 & $340-342$ \\
\hline $\begin{array}{l}\text { Monocyte-derived } \\
\text { dendritic cells }\end{array}$ & yes & yes & +++ & yes & $\begin{array}{l}\text { Bender et al., 1996; Pickl et al., 1996; } \\
\text { Lutz et al., 1999; Robinson et al., 2001; } \\
\text { Davis et al., 2003; Gilboa et al., } 2007\end{array}$ & $\begin{array}{l}15,250,251 \\
343-345\end{array}$ \\
\hline $\begin{array}{l}\text { Autologous progenitor- } \\
\text { derived DC }\end{array}$ & yes & yes/no & +++ & yes & $\begin{array}{l}\text { Bancherau et al., 2001; Lu et al., 2004; } \\
\text { Palucka et al., 2005; Fay et al., 2006; } \\
\text { Palucka et al., } 2008\end{array}$ & $253,346-349$ \\
\hline Tolerogenic DC & yes & yes & +++ & yes & $\begin{array}{l}\text { Jonuleit et al., 2000; Dhocapkar et al., 2001; } \\
\text { Steinman et al., 2003; Sato et al., } 2003\end{array}$ & $\begin{array}{l}255,260 \\
261,350\end{array}$ \\
\hline $\begin{array}{l}\text { Insect cells } \\
\text { (Drosophila melanogaster) }\end{array}$ & yes & no & +++ & yes & $\begin{array}{l}\text { Jackson et al., 1992; Cai et al., 1996; } \\
\text { Mitchell et al., } 2002\end{array}$ & $40,351-353$ \\
\hline Mouse fibroblasts & yes & yes & +++ & no & Latouche et al., 2002; Papanicolaou et al., 2003 & 354,355 \\
\hline K562/K32 cells & no & no & +++ & no & Maus et al., 2002; Thomas et al., 2002 & 356,357 \\
\hline Daudi cells & yes & no & +++ & no & Obermann et al., 2007 & 358 \\
\hline BW 5147 cells & no & no & +++ & no & Pfistershammer et al., 2006; Kober et al., 2008 & 165,359 \\
\hline
\end{tabular}


as a consequence of a broad range of physiological and pathological processes such as cellular activation and differentiation [242-244], among others. Due to the expression of pMHC, costimulatory and adhesion molecules, B cell- and DC-derived exosomes have the ability to induce antigen-specific $\mathrm{T}$ cell responses in vivo [241] and, to a lesser extent, also in vitro [238], although the exact mechanism for their functional activity is still enigmatic. While some studies demonstrated that exosome function required the help of APC [245-247], others indicated that exosomes directly induced $\mathrm{T}$ lymphocyte stimulation [248]. Since exosomes can be efficiently loaded with antigenic peptides by pulse labeling, they are also capable of inducing antigen-specific cellular responses [238, 249]. However, since VLP are amenable to decoration with molecules of choice, VLP seem to represent a more versatile antigen-presenting platform than exosomes [134137].

\section{VLP Compared to Cellular APC Systems}

Antigen-specific T cell activation is best achieved by antigen-loaded professional APC, e.g. DC, macrophages, or $\mathrm{B}$ cells, the gold standard for interventional studies being monocyte-derived dendritic cells (mdDC) [250, 251]. Antigen-pulsed mdDC are currently used as vaccines in cancer patients and several clinical trials demonstrated an induction of immunity to tumor antigens, although objective tumor regression still seems to be limited [68, $252,253]$. The culture and differentiation of mdDC entails the isolation of sufficient numbers of mononuclear cells from patients or histocompatible healthy donors by leukapheresis [250]. Such individual medicine is timeconsuming, inherently expensive, and production-wise often inefficient, e.g. for patients undergoing cytotoxic chemotherapy [254]. Moreover, inadequately matured DCs might even downregulate immunity, generate CD4+CD25+ Treg cells, and thus induce peripheral tolerance to the putative tumor antigen [255].

The apparently broad tolerogenic potential of in vitroinduced DC by (i) pharmacological drugs such as aspirin, rapamycin, dexamethasone, and vitamin D3 [256-259]; (ii) the transgenic overexpression of immunosuppressive molecules, or (iii) the administration of exogenous cytokines (e.g. TGF- $\beta$, IL-10, GM-CSF, and IL-4) opens, however, new and appealing ways for the induction of Tregs $[260,261]$. Such tolerance-inducing protocols might become useful for the treatment of autoimmune disorders, chronic inflammation, allergic diseases, and as graft rejection [262-264]. It is important to note that recent studies have demonstrated that purified exosomes from IL- 10-treated BM DCs were able to suppress delayed-type hypersensitivity reactions [265], and indoleamine 2,3-dioxygenase (IDO) overexpressing DC-derived exosomes displayed immunosuppressive and anti-inflammatory features [266]. Thus, in comparison to tolerogenic VLP $[136,137]$, regulatory DC-derived exosomes may represent another cell-free therapy for the treatment of allergy or autoimmune diseases. However, the clinical use of in vitro-generated tolerogenic DC and DC-derived exosomes might bear substantial inherent disadvantages such as the requirement of a large number of HLAmatched DC and the achievement of a relatively stable, immature, or regulatory phenotype of DC in culture.

\section{Fluorosomes: A Convenient New Reagent to Detect and Block Multivalent and Complex Receptor-Ligand Interactions}

In the past, the translational fusion of viral proteins with green fluorescent protein has been used to elucidate the cellular pathways of infectious viruses [267, 268]. Since lipid rafts serve as a meeting point for GPI-anchored surface molecules and the viral core proteins, fluorescent proteins $\mathrm{N}$-terminally linked to the viral matrix protein MA of MoMLV generate fluorescently labeled VLP that can be used to track receptor-ligand interactions in different settings. In a recent report, VLP labeled with recombinant fluorescent proteins of cnidarian origin and decorated with IL-2 specifically identified normal and malignant IL-2R+ lymphocytes by flow cytometry [136]. Notably, the fluorescent VLP platform could also accommodate multi-subunit ligands or receptors which are otherwise not easy to express in the appropriate configuration. In further applications, FS might facilitate the detection of low-affinity interactions between monomeric receptor-ligand pairs, and fluorescently labeled VLP could serve as a versatile tool to track immunomodulatory VLP in vivo. Due to their simple generation and broad applicability, FS might serve as valuable tools in different fields of basic immunological research as well as for diagnostic purposes.

\section{Conclusion and Perspectives}

In this study we discuss the advantages and shortcomings of different approaches for the antigen-nonspecific and antigen-specific activation of $\mathrm{T}$ lymphocytes by a novel immunomodulatory tool, i.e. VLP decorated with immunomodulatory molecules of choice. VLP are derived from common producer cells, i.e. HEK-293 epithelial 
cells, which are suitable for GMP protocols and should per se - due to their human origin - only show minor immunogenicity in future therapeutic applications in humans. VLP production is induced by simple transfection. At this level, VLP can be selectively decorated with preformed pMHC complexes, costimulatory molecules, membranebound cytokines, and cytokine receptors, respectively, if desired in a fluorescent form. Consequently, VLP can be regarded as 'packages of information' with the capacity to efficiently target antigen-specific $\mathrm{T}$ lymphocytes by the delivery of antigen-specific and cosignals of choice. Depending on the quality of the cosignals used, VLP offer the possibility to activate and expand, anergize, or polarize antigen-specific $\mathrm{T}$ lymphocytes. Given their high versatility in basic studies, the detailed analysis of the therapeutic usefulness of VLP in more clinically oriented studies is clearly warranted in the future. Along those lines, one could envision a much broader range of applications with VLP serving as packages transporting specific cargo - e.g. in the form of nonintegrating genetic information or a pharmaceutical compound - to modulate the function/survival of target cells which they specifically recognize by surface ligand-receptor interactions.

\section{Acknowledgements}

We are in debt to Ms. Daniela Haiderer, Ms. Rosemarie Schmetterer and Dr. Peter Steinberger for their critical reading of this manuscript. This review was supported by grant SFB F1816B13 of the Austrian Science Foundation; the Christian Doppler Society, Austria; Österreichische Forschungsförderungsgesellschaft grant 812079, and Biomay, Austria.

\section{References}

1 Medzhitov R, Janeway CA Jr: Innate immunity: impact on the adaptive immune response. Curr Opin Immunol 1997;9:4-9.

$\checkmark 2$ Fearon DT, Locksley RM: The instructive role of innate immunity in the acquired immune response. Science 1996;272:50-53.

-3 Banchereau J, Steinman RM: Dendritic cells and the control of immunity. Nature 1998; 392:245-252.

4 Steinman RM, Witmer MD: Lymphoid dendritic cells are potent stimulators of the primary mixed leukocyte reaction in mice. Proc Natl Acad Sci USA 1978;75:5132-5136.

$\checkmark 5$ Macatonia SE, Taylor PM, Knight SC, Askonas BA: Primary stimulation by dendritic cells induces antiviral proliferative and cytotoxic T cell responses in vitro. J Exp Med 1989;169:1255-1264.

-6 Boon T, Cerottini JC, Van den Eynde B, van der Bruggen P, Van Pel A: Tumor antigens recognized by T lymphocytes. Annu Rev Immunol 1994;12:337-365.

7 Schuler G, Steinman RM: Dendritic cells as adjuvants for immune-mediated resistance to tumors. J Exp Med 1997;186:1183-1187.

$\checkmark 8$ Thurner B, Haendle I, Roder C, Dieckmann D, Keikavoussi P, Jonuleit H, Bender A, Maczek C, Schreiner D, von den Driesch P, Brocker EB, Steinman RM, Enk A, Kampgen E, Schuler G: Vaccination with mage-3A1 peptide-pulsed mature, monocyte-derived dendritic cells expands specific cytotoxic T cells and induces regression of some metastases in advanced stage IV melanoma. J Exp Med 1999;190:1669-1678.
9 Van Der Bruggen P, Zhang Y, Chaux P, Stroobant V, Panichelli C, Schultz ES, Chapiro J, Van Den Eynde BJ, Brasseur F, Boon T: Tumor-specific shared antigenic peptides recognized by human T cells. Immunol Rev 2002;188:51-64.

10 Schuler-Thurner B, Schultz ES, Berger TG, Weinlich G, Ebner S, Woerl P, Bender A, Feuerstein B, Fritsch PO, Romani N, Schuler G: Rapid induction of tumor-specific type 1 $\mathrm{T}$ helper cells in metastatic melanoma patients by vaccination with mature, cryopreserved, peptide-loaded monocyte-derived dendritic cells. J Exp Med 2002;195:1279_ 1288.

11 Ludewig B, Odermatt B, Ochsenbein AF, Zinkernagel RM, Hengartner $\mathrm{H}$ : Role of dendritic cells in the induction and maintenance of autoimmune diseases. Immunol Rev 1999; 169:45-54

$12 \mathrm{Lu}$ L, Thomson AW: Manipulation of dendritic cells for tolerance induction in transplantation and autoimmune disease. Transplantation 2002;73:S19-S22.

13 Larche M, Akdis CA, Valenta R: Immunological mechanisms of allergen-specific immunotherapy. Nat Rev Immunol 2006;6: 761-771.

-14 Caux C, Dezutter-Dambuyant C, Schmitt D, Banchereau J: GM-CSF and TNF-alpha cooperate in the generation of dendritic Langerhans cells. Nature 1992;360:258-261.

15 Pickl WF, Majdic O, Kohl P, Stockl J, Riedl E, Scheinecker C, Bello-Fernandez C, Knapp $\mathrm{W}$ : Molecular and functional characteristics of dendritic cells generated from highly purified CD14+ peripheral blood monocytes. J Immunol 1996;157:3850-3859.
16 Reid CD, Fryer PR, Clifford C, Kirk A, Tikerpae J, Knight SC: Identification of hematopoietic progenitors of macrophages and dendritic Langerhans cells (DL-CFU) in human bone marrow and peripheral blood. Blood 1990;76:1139-1149.

17 Strunk D, Rappersberger K, Egger C, Strobl H, Kromer E, Elbe A, Maurer D, Stingl G: Generation of human dendritic cells/Langerhans cells from circulating CD34+ hematopoietic progenitor cells. Blood 1996;87: 1292-1302.

$>18$ Fong L, Engleman EG: Dendritic cells in cancer immunotherapy. Annu Rev Immunol 2000; $18: 245-273$.

19 Vulink A, Radford KJ, Melief C, Hart DN: Dendritic cells in cancer immunotherapy. Adv Cancer Res 2008;99:363-407.

20 Coyle AJ, Gutierrez-Ramos JC: The expanding B7 superfamily: increasing complexity in costimulatory signals regulating $\mathrm{T}$ cell function. Nat Immunol 2001;2:203-209.

-21 Lanzavecchia A, Sallusto F: Antigen decoding by T lymphocytes: from synapses to fate determination. Nat Immunol 2001;2:487492.

22 Montoya MC, Sancho D, Vicente-Manzanares M, Sanchez-Madrid F: Cell adhesion and polarity during immune interactions. Immunol Rev 2002;186:68-82.

23 Bretscher P, Cohn M: A theory of self-nonself discrimination. Science 1970;169:10421049 .

24 Lafferty KJ, Cunningham AJ: A new analysis of allogeneic interactions. Aust J Exp Biol Med Sci 1975;53:27-42. 
-25 Eckels DD, Sell TW, Bronson SR, Johnson AH, Hartzman RJ, Lamb JR: Human helper T-cell clones that recognize different influenza hemagglutinin determinants are restricted by different HLA-D region epitopes. Immunogenetics 1984;19:409-423.

-26 Shevach EM, Rosenthal AS: Function of macrophages in antigen recognition by guinea pig $\mathrm{T}$ lymphocytes. II. Role of the macrophage in the regulation of genetic control of the immune response. J Exp Med 1973;138:1213-1229.

27 Zinkernagel RM, Doherty PC: Restriction of in vitro T cell-mediated cytotoxicity in lymphocytic choriomeningitis within a syngeneic or semiallogeneic system. Nature 1974; 248:701-702.

-28 Curtsinger JM, Schmidt CS, Mondino A, Lins DC, Kedl RM, Jenkins MK, Mescher MF: Inflammatory cytokines provide a third signal for activation of naive CD4+ and CD8+ T cells. J Immunol 1999;162:32563262 .

-29 Setterblad N, Becart S, Charron D, Mooney $\mathrm{N}$ : B cell lipid rafts regulate both peptide-dependent and peptide-independent APC-T cell interaction. J Immunol 2004;173:18761886.

-30 Stefanova I, Horejsi V, Ansotegui IJ, Knapp W, Stockinger H: GPI-anchored cell-surface molecules complexed to protein tyrosine kinases. Science 1991;254:1016-1019.

-31 Tavano R, Contento RL, Baranda SJ, Soligo M, Tuosto L, Manes S, Viola A: CD28 interaction with filamin-A controls lipid raft accumulation at the T-cell immunological synapse. Nat Cell Biol 2006;8:1270-1276.

- 32 Viola A, Schroeder S, Sakakibara Y, Lanzavecchia A: T lymphocyte costimulation mediated by reorganization of membrane microdomains. Science 1999;283:680-682.

-33 Anderson HA, Hiltbold EM, Roche PA: Concentration of MHC class II molecules in lipid rafts facilitates antigen presentation. Nat Immunol 2000;1:156-162.

>34 Monks CR, Freiberg BA, Kupfer H, Sciaky N, Kupfer A: Three-dimensional segregation of supramolecular activation clusters in T cells. Nature 1998;395:82-86.

- 35 Viola A, Lanzavecchia A: T cell activation determined by $\mathrm{T}$ cell receptor number and tunable thresholds. Science 1996;273:104106.

>36 Hathcock KS, Laszlo G, Pucillo C, Linsley P, Hodes RJ: Comparative analysis of B7-1 and B7-2 costimulatory ligands: expression and function. J Exp Med 1994;180:631-640.

-37 Hutloff A, Dittrich AM, Beier KC, Eljaschewitsch B, Kraft R, Anagnostopoulos I, Kroczek RA: ICOS is an inducible T-cell costimulator structurally and functionally related to CD28. Nature 1999;397:263-266.
38 Krensky AM, Sanchez-Madrid F, Robbins E, Nagy JA, Springer TA, Burakoff SJ: The functional significance, distribution, and structure of LFA-1, LFA-2, and LFA-3: cell surface antigens associated with CTL-target interactions. J Immunol 1983;131:611-616.

39 Stuber E, Strober W: The T cell-B cell interaction via OX40-OX40L is necessary for the $\mathrm{T}$ cell-dependent humoral immune response. J Exp Med 1996;183:979-989.

40 Cai Z, Sprent J: Influence of antigen dose and costimulation on the primary response of CD8+ T cells in vitro. J Exp Med 1996;183: 2247-2257.

41 Carreno BM, Collins M: The B7 family of ligands and its receptors: new pathways for costimulation and inhibition of immune responses. Annu Rev Immunol 2002;20:29-53.

42 Watts TH: TNF/TNFR family members in costimulation of T cell responses. Annu Rev Immunol 2005;23:23-68.

43 Brunet JF, Denizot F, Luciani MF, RouxDosseto M, Suzan M, Mattei MG, Golstein P: A new member of the immunoglobulin superfamily - CTLA-4. Nature 1987;328:267270.

44 Latchman Y, Wood CR, Chernova T, Chaudhary D, Borde M, Chernova I, Iwai Y, Long AJ, Brown JA, Nunes R, Greenfield EA, Bourque K, Boussiotis VA, Carter LL, Carreno $\mathrm{BM}$, Malenkovich $\mathrm{N}$, Nishimura $\mathrm{H}$, Okazaki T, Honjo T, Sharpe AH, Freeman GJ: PD-L2 is a second ligand for PD-1 and inhibits T cell activation. Nat Immunol 2001; 2:261-268.

-45 Nishimura H, Minato N, Nakano T, Honjo T: Immunological studies on PD-1 deficient mice: implication of PD-1 as a negative regulator for B cell responses. Int Immunol 1998; 10:1563-1572.

-46 Ragazzo JL, Ozaki ME, Karlsson L, Peterson PA, Webb SR: Costimulation via lymphocyte function-associated antigen 1 in the absence of CD28 ligation promotes anergy of naive CD4+ T cells. Proc Natl Acad Sci USA 2001; 98:241-246

47 Schwartz RH: T cell anergy. Annu Rev Immunol 2003;21:305-334.

48 Vella AT, Mitchell T, Groth B, Linsley PS, Green JM, Thompson CB, Kappler JW, Marrack P: CD28 engagement and proinflammatory cytokines contribute to $\mathrm{T}$ cell expansion and long-term survival in vivo. J Immunol 1997;158:4714-4720.

49 Curtsinger JM, Valenzuela JO, Agarwal P, Lins D, Mescher MF: Type I IFNs provide a third signal to CD8 T cells to stimulate clonal expansion and differentiation. J Immunol 2005;174:4465-4469.

50 Kurt-Jones EA, Hamberg S, Ohara J, Paul WE, Abbas AK: Heterogeneity of helper/inducer T lymphocytes. I. Lymphokine production and lymphokine responsiveness. J Exp Med 1987;166:1774-1787.
51 Valenzuela J, Schmidt C, Mescher M: The roles of IL-12 in providing a third signal for clonal expansion of naive CD8 T cells. J Immunol 2002;169:6842-6849.

52 Conlon PJ, Morrissey PJ, Nordan RP, Grabstein KH, Prickett KS, Reed SG, Goodwin R, Cosman D, Namen AE: Murine thymocytes proliferate in direct response to interleukin-7. Blood 1989;74:1368-1373.

53 Grabstein KH, Eisenman J, Shanebeck K, Rauch C, Srinivasan S, Fung V, Beers C, Richardson J, Schoenborn MA, Ahdieh M, et al: Cloning of a $\mathrm{T}$ cell growth factor that interacts with the beta chain of the interleukin-2 receptor. Science 1994;264:965-968.

54 Morgan DA, Ruscetti FW, Gallo R: Selective in vitro growth of $\mathrm{T}$ lymphocytes from normal human bone marrows. Science 1976;193: 1007-1008.

55 Ohara J, Paul WE: Receptors for B-cell stimulatory factor-1 expressed on cells of haematopoietic lineage. Nature 1987;325:537-540.

56 Akdis CA, Blaser K: IL-10-induced anergy in peripheral $\mathrm{T}$ cell and reactivation by microenvironmental cytokines: two key steps in specific immunotherapy. FASEB J 1999;13: 603-609.

57 Chen W, Jin W, Hardegen N, Lei KJ, Li L, Marinos N, McGrady G, Wahl SM: Conversion of peripheral CD4+CD25- naive T cells to $\mathrm{CD} 4+\mathrm{CD} 25+$ regulatory $\mathrm{T}$ cells by TGFbeta induction of transcription factor Foxp3. J Exp Med 2003;198:1875-1886.

58 Kehrl JH, Wakefield LM, Roberts AB, Jakowlew S, Alvarez-Mon M, Derynck R, Sporn MB, Fauci AS: Production of transforming growth factor beta by human T lymphocytes and its potential role in the regulation of T cell growth. J Exp Med 1986;163: 1037-1050.

59 Dooms H, Wolslegel K, Lin P, Abbas AK: Interleukin-2 enhances CD4+ T cell memory by promoting the generation of IL-7R alphaexpressing cells. J Exp Med 2007;204:547557.

60 Refaeli Y, Van Parijs L, London CA, Tschopp J, Abbas AK: Biochemical mechanisms of IL2-regulated Fas-mediated T cell apoptosis. Immunity 1998;8:615-623.

61 Abbas AK, Murphy KM, Sher A: Functional diversity of helper T lymphocytes. Nature 1996;383:787-793.

-62 Mosmann TR, Cherwinski H, Bond MW, Giedlin MA, Coffman RL: Two types of murine helper T cell clone. I. Definition according to profiles of lymphokine activities and secreted proteins. J Immunol 1986;136: 2348-2357.

63 Maggi E, Parronchi P, Manetti R, Simonelli C, Piccinni MP, Rugiu FS, De Carli M, Ricci M, Romagnani S: Reciprocal regulatory effects of IFN-gamma and IL-4 on the in vitro development of human Th1 and Th2 clones. J Immunol 1992;148:2142-2147. 
64 Manetti R, Parronchi P, Giudizi MG, Piccinni MP, Maggi E, Trinchieri G, Romagnani S: Natural killer cell stimulatory factor (interleukin 12 [IL-12]) induces $\mathrm{T}$ helper type 1 (Th1)-specific immune responses and inhibits the development of IL-4-producing Th cells. J Exp Med 1993;177:1199-1204.

65 Parronchi P, De Carli M, Manetti R, Simonelli C, Sampognaro S, Piccinni MP, Macchia D, Maggi E, Del Prete G, Romagnani S: IL-4 and IFN (alpha and gamma) exert opposite regulatory effects on the development of cytolytic potential by Th1 or Th2 human T cell clones. J Immunol 1992;149:29772983.

-66 Tang L, Benjaponpitak S, DeKruyff RH, Umetsu DT: Reduced prevalence of allergic disease in patients with multiple sclerosis is associated with enhanced IL-12 production. J Allergy Clin Immunol 1998;102:428-435.

-67 Dignani MC, Rex JH, Chan KW, Dow G, deMagalhaes-Silverman M, Maddox A, Walsh T, Anaissie E: Immunomodulation with interferon-gamma and colony-stimulating factors for refractory fungal infections in patients with leukemia. Cancer 2005; 104 : 199-204.

- 68 Koski GK, Cohen PA, Roses RE, Xu S, Czerniecki BJ: Reengineering dendritic cellbased anti-cancer vaccines. Immunol Rev 2008;222:256-276.

69 Murray HW: Cytokines as antimicrobial therapy for the T cell-deficient patient: prospects for treatment of nonviral opportunistic infections. Clin Infect Dis 1993;17(suppl 2):S407-S413.

70 Spolski R, Leonard WJ: The Yin and Yang of interleukin-21 in allergy, autoimmunity and cancer. Curr Opin Immunol 2008;20:295301.

-71 Weiss JM, Subleski JJ, Wigginton JM, Wiltrout RH: Immunotherapy of cancer by IL12-based cytokine combinations. Expert Opin Biol Ther 2007;7:1705-1721.

-72 Audibert FM, Lise LD: Adjuvants: current status, clinical perspectives and future prospects. Trends Pharmacol Sci 1993;14:174178.

-73 Gupta RK, Siber GR: Adjuvants for human vaccines - current status, problems and future prospects. Vaccine 1995;13:1263-1276.

-74 Bryant M, Ratner L: Myristoylation-dependent replication and assembly of human immunodeficiency virus 1. Proc Natl Acad Sci USA 1990;87:523-527.

-75 Graham DR, Chertova E, Hilburn JM, Arthur LO, Hildreth JE: Cholesterol depletion of human immunodeficiency virus type 1 and simian immunodeficiency virus with beta-cyclodextrin inactivates and permeabilizes the virions: evidence for virion-associated lipid rafts. J Virol 2003;77:82378248.
76 Laliberte JP, McGinnes LW, Peeples ME, Morrison TG: Integrity of membrane lipid rafts is necessary for the ordered assembly and release of infectious Newcastle disease virus particles. J Virol 2006;80:10652-10662.

77 Manie SN, de Breyne S, Vincent S, Gerlier D: Measles virus structural components are enriched into lipid raft microdomains: a potential cellular location for virus assembly. J Virol 2000;74:305-311.

78 Nguyen DH, Hildreth JE: Evidence for budding of human immunodeficiency virus type 1 selectively from glycolipid-enriched membrane lipid rafts. J Virol 2000;74:32643272 .

79 Pickl WF, Pimentel-Muinos FX, Seed B: Lipid rafts and pseudotyping. J Virol 2001;75: 7175-7183.

80 Scheiffele P, Roth MG, Simons K: Interaction of influenza virus haemagglutinin with sphingolipid-cholesterol membrane domains via its transmembrane domain. EMBO J 1997;16:5501-5508.

81 Pape KA, Khoruts A, Mondino A, Jenkins MK: Inflammatory cytokines enhance the in vivo clonal expansion and differentiation of antigen-activated CD4+ T cells. J Immuno 1997;159:591-598.

82 Simons K, Ikonen E: Functional rafts in cell membranes. Nature 1997;387:569-572.

83 Guerriero CJ, Lai Y, Weisz OA: Differential sorting and Golgi export requirements for raft-associated and raft-independent apical proteins along the biosynthetic pathway. J Biol Chem 2008;283:18040-18047.

84 Nichols BJ, Lippincott-Schwartz J: Endocytosis without clathrin coats. Trends Cell Biol 2001;11:406-412.

85 Keller P, Simons K: Cholesterol is required for surface transport of influenza virus hemagglutinin. J Cell Biol 1998;140:1357-1367.

86 Subtil A, Gaidarov I, Kobylarz K, Lampson MA, Keen JH, McGraw TE: Acute cholesterol depletion inhibits clathrin-coated pit budding. Proc Natl Acad Sci USA 1999;96:67756780 .

87 Wang Y, Thiele C, Huttner WB: Cholesterol is required for the formation of regulated and constitutive secretory vesicles from the trans-Golgi network. Traffic 2000;1:952962.

88 Xavier R, Brennan T, Li Q, McCormack C, Seed B: Membrane compartmentation is required for efficient $\mathrm{T}$ cell activation. Immunity 1998;8:723-732.

89 Brown DA, London E: Structure and origin of ordered lipid domains in biological membranes. J Membr Biol 1998;164:103-114.

90 Radhakrishnan A, McConnell HM: Condensed complexes of cholesterol and phospholipids. Biophys J 1999;77:1507-1517.

91 Brown DA: Interactions between GPIanchored proteins and membrane lipids. Trends Cell Biol 1992;2:338-343.
\$2 Legler DF, Doucey MA, Schneider P, Chapatte L, Bender FC, Bron C: Differential insertion of GPI-anchored GFPs into lipid rafts of live cells. FASEB J 2005;19:73-75.

$\$ 93$ Paulick MG, Bertozzi CR: The glycosylphosphatidylinositol anchor: a complex membrane-anchoring structure for proteins. Biochemistry 2008;47:6991-7000.

$\$ 94$ Bijlmakers MJ: Protein acylation and localization in T cell signaling (Review). Mol Membr Biol 2009;26:93-103.

95 Horejsi V: The roles of membrane microdomains (rafts) in T cell activation. Immunol Rev 2003;191:148-164.

\$96 Resh MD: Membrane targeting of lipid modified signal transduction proteins. Subcell Biochem 2004;37:217-232.

97 Resh MD: Palmitoylation of ligands, receptors, and intracellular signaling molecules. Sci STKE 2006;2006:re14.

$\checkmark 98$ Douglass AD, Vale RD: Single-molecule microscopy reveals plasma membrane microdomains created by protein-protein networks that exclude or trap signaling molecules in T cells. Cell 2005;121:937-950.

$\$ 99$ Hancock JF: Lipid rafts: contentious only from simplistic standpoints. Nat Rev Mol Cell Biol 2006;7:456-462.

100 Larson DR, Gosse JA, Holowka DA, Baird BA, Webb WW: Temporally resolved interactions between antigen-stimulated IgE receptors and Lyn kinase on living cells. J Cell Biol 2005; 171:527-536.

101 Kusumi A, Ike H, Nakada C, Murase K, Fujiwara T: Single-molecule tracking of membrane molecules: plasma membrane compartmentalization and dynamic assembly of raft-philic signaling molecules. Semin Immunol 2005; 17:3-21.

102 Kusumi A, Koyama-Honda I, Suzuki K: Molecular dynamics and interactions for creation of stimulation-induced stabilized rafts from small unstable steady-state rafts. Traffic 2004;5:213-230.

103 Mayor S, Rao M: Rafts: scale-dependent, active lipid organization at the cell surface. Traffic 2004;5:231-240.

104 Sharma P, Varma R, Sarasij RC, Ira, Gousset K, Krishnamoorthy G, Rao M, Mayor S: Nanoscale organization of multiple GPIanchored proteins in living cell membranes. Cell 2004;116:577-589.

105 Dietrich C, Volovyk ZN, Levi M, Thompson NL, Jacobson K: Partitioning of Thy-1, GM1, and cross-linked phospholipid analogs into lipid rafts reconstituted in supported model membrane monolayers. Proc Natl Acad Sci USA 2001;98:10642-10647.

106 Kahya N, Brown DA, Schwille P: Raft partitioning and dynamic behavior of human placental alkaline phosphatase in giant unilamellar vesicles. Biochemistry 2005; 44:7479-7489. 
107 Simons K, Vaz WL: Model systems, lipid rafts, and cell membranes. Annu Rev Biophys Biomol Struct 2004;33:269-295.

108 Anderson RG: Caveolae: where incoming and outgoing messengers meet. Proc Natl Acad Sci USA 1993;90:10909-10913.

109 Delacour D, Jacob R: Apical protein transport. Cell Mol Life Sci 2006;63:2491-2505.

$>110$ Kirkham M, Parton RG: Clathrin-independent endocytosis: new insights into caveolae and non-caveolar lipid raft carriers. Biochim Biophys Acta 2005;1746:349-363.

-111 Paladino S, Sarnataro D, Pillich R, Tivodar S, Nitsch L, Zurzolo C: Protein oligomerization modulates raft partitioning and apical sorting of GPI-anchored proteins. J Cell Biol 2004;167:699-709.

-112 Gaus K, Chklovskaia E, Fazekas de St Groth B, Jessup W, Harder T: Condensation of the plasma membrane at the site of T lymphocyte activation. J Cell Biol 2005;171:121131.

-113 Gupta N, DeFranco AL: Lipid rafts and B cell signaling. Semin Cell Dev Biol 2007;18: 616-626.

-114 Horejsi V, Drbal K, Cebecauer M, Cerny J, Brdicka T, Angelisova P, Stockinger H: GPImicrodomains: a role in signalling via immunoreceptors. Immunol Today 1999;20: 356-361.

-115 Xavier R, Seed B: Membrane compartmentation and the response to antigen. Curr Opin Immunol 1999;11:265-269.

- 116 Arreaza G, Brown DA: Sorting and intracellular trafficking of a glycosylphosphatidylinositol-anchored protein and two hybrid transmembrane proteins with the same ectodomain in Madin-Darby canine kidney epithelial cells. J Biol Chem 1995; 270:23641-23647.

- 117 Butikofer P, Kuypers FA, Xu CM, Chiu DT, Lubin B: Enrichment of two glycosyl-phosphatidylinositol-anchored proteins, acetylcholinesterase and decay accelerating factor, in vesicles released from human red blood cells. Blood 1989;74:1481-1485.

-118 Brewis IA, Ferguson MA, Mehlert A, Turner AJ, Hooper NM: Structures of the glycosyl-phosphatidylinositol anchors of porcine and human renal membrane dipeptidase: comprehensive structural studies on the porcine anchor and interspecies comparison of the glycan core structures. Biol Chem 1995;270:22946-22956.

-119 Dustin ML, Selvaraj P, Mattaliano RJ, Springer TA: Anchoring mechanisms for LFA-3 cell adhesion glycoprotein at membrane surface. Nature 1987;329:846-848.

$\checkmark 120$ Treumann A, Lifely MR, Schneider P, Ferguson MA: Primary structure of CD52. J Biol Chem 1995;270:6088-6099.

-121 Simmons DL, Tan S, Tenen DG, NicholsonWeller A, Seed B: Monocyte antigen CD14 is a phospholipid anchored membrane protein. Blood 1989;73:284-289.
122 Shen F, Ross JF, Wang X, Ratnam M: Identification of a novel folate receptor, a truncated receptor, and receptor type beta in hematopoietic cells: cDNA cloning, expression, immunoreactivity, and tissue specificity. Biochemistry 1994;33:1209-1215.

123 Simmons D, Seed B: The Fc gamma receptor of natural killer cells is a phospholipidlinked membrane protein. Nature 1988; 333:568-570.

124 Ratnoff WD, Knez JJ, Prince GM, Okada H, Lachmann PJ, Medof ME: Structural properties of the glycoplasmanylinositol anchor phospholipid of the complement membrane attack complex inhibitor CD59. Clin Exp Immunol 1992;87:415-421.

125 Brown DA, Crise B, Rose JK: Mechanism of membrane anchoring affects polarized expression of two proteins in MDCK cells. Science 1989;245:1499-1501.

126 Lisanti MP, Caras IW, Davitz MA, Rodriguez-Boulan E: A glycophospholipid membrane anchor acts as an apical targeting signal in polarized epithelial cells. J Cell Biol 1989;109:2145-2156

127 Alland L, Peseckis SM, Atherton RE, Berthiaume L, Resh MD: Dual myristylation and palmitylation of Src family member p59fyn affects subcellular localization. J Biol Chem 1994;269:16701-16705

128 Arcaro A, Gregoire C, Bakker TR, Baldi L, Jordan M, Goffin L, Boucheron N, Wurm F, van der Merwe PA, Malissen B, Luescher IF: CD8beta endows CD8 with efficient coreceptor function by coupling T cell receptor/ CD3 to raft-associated CD8/p56(lck) complexes. J Exp Med 2001;194:1485-1495.

129 Arcaro A, Gregoire C, Boucheron N, Stotz S, Palmer E, Malissen B, Luescher IF: Essential role of CD8 palmitoylation in CD8 coreceptor function. J Immunol 2000;165: 2068-2076

130 Crise B, Rose JK: Identification of palmitoylation sites on CD4, the human immunodeficiency virus receptor. J Biol Chem 1992;267:13593-13597.

131 Draberova L, Draber P: Thy-1 glycoprotein and src-like protein-tyrosine kinase p53/ p56lyn are associated in large detergent-resistant complexes in rat basophilic leukemia cells. Proc Natl Acad Sci USA 1993;90: 3611-3615.

132 Resh MD: Fatty acylation of proteins: new insights into membrane targeting of myristoylated and palmitoylated proteins. Biochim Biophys Acta 1999;1451:1-16.

133 van't Hof W, Resh MD: Dual fatty acylation of p59(Fyn) is required for association with the $T$ cell receptor zeta chain through phosphotyrosine-Src homology domain-2 interactions. J Cell Biol 1999;145:377-389.
134 Derdak SV, Kueng HJ, Leb VM, Neunkirchner A, Schmetterer KG, Bielek E, Majdic O, Knapp W, Seed B, Pickl WF: Direct stimulation of T lymphocytes by immunosomes: virus-like particles decorated with T cell receptor/CD3 ligands plus costimulatory molecules. Proc Natl Acad Sci USA 2006; 103:13144-13149.

135 Kueng HJ, Leb VM, Haiderer D, Raposo G, Thery C, Derdak SV, Schmetterer KG, Neunkirchner A, Sillaber C, Seed B, Pickl WF: General strategy for decoration of enveloped viruses with functionally active lipid-modified cytokines. J Virol 2007;81: 8666-8676.

136 Kueng HJ, Manta C, Haiderer D, Leb VM, Schmetterer KG, Neunkirchner A, Byrne RA, Scheinecker C, Steinberger P, Seed B, Pickl WF: Fluorosomes: a convenient new reagent to detect and block multivalent and complex receptor-ligand interactions. FASEB J 2010;24:1572-1582.

137 Leb VM, Jahn-Schmid B, Kueng HJ, Schmetterer KG, Haiderer D, Neunkirchner A, Fischer GF, Hartl A, Thalhamer J, Steinberger P, Bohle B, Seed B, Pickl WF: Modulation of allergen-specific T-lymphocyte function by virus-like particles decorated with HLA class II molecules. J Allergy Clin Immunol 2009;124:121-128.

138 Leb VM, Jahn-Schmid B, Schmetterer KG, Kueng HJ, Haiderer D, Neunkirchner A, Fischer GF, Nissler K, Hartl A, Thalhamer J, Bohle B, Seed B, Pickl WF: Molecular and functional analysis of the antigen receptor of Art v 1-specific helper T lymphocytes. J Allergy Clin Immunol 2008;121:64-71.

139 Huttner WB, Zimmerberg J: Implications of lipid microdomains for membrane curvature, budding and fission. Curr Opin Cell Biol 2001;13:478-484.

140 Barman S, Nayak DP: Analysis of the transmembrane domain of influenza virus neuraminidase, a type II transmembrane glycoprotein, for apical sorting and raft association. J Virol 2000;74:6538-6545.

141 Zhang J, Leser GP, Pekosz A, Lamb RA: The cytoplasmic tails of the influenza virus spike glycoproteins are required for normal genome packaging. Virology 2000;269: 325-334.

142 Scheiffele P, Rietveld A, Wilk T, Simons K: Influenza viruses select ordered lipid domains during budding from the plasma membrane. J Biol Chem 1999;274:20382044.

143 Pepinsky RB, Vogt VM: Fine-structure analyses of lipid-protein and protein-protein interactions of gag protein p19 of the avian sarcoma and leukemia viruses by cyanogen bromide mapping. J Virol 1984;52: 145-153.

144 Hansen M, Jelinek L, Whiting S, Barklis E: Transport and assembly of gag proteins into Moloney murine leukemia virus. J Virol 1990;64:5306-5316. 
-145 Fu X, Phillips N, Jentoft J, Tuazon PT, Traugh JA, Leis J: Site-specific phosphorylation of avian retrovirus nucleocapsid protein pp12 regulates binding to viral RNA: evidence for different protein conformations. J Biol Chem 1985;260:9941-9947.

146 Gottlinger HG: The HIV-1 assembly machine. AIDS 2001;15(suppl 5):S13-S20.

-147 Lindwasser OW, Resh MD: Multimerization of human immunodeficiency virus type 1 Gag promotes its localization to barges, raft-like membrane microdomains. J Virol 2001;75:7913-7924.

148 Ono A, Freed EO: Plasma membrane rafts play a critical role in HIV-1 assembly and release. Proc Natl Acad Sci USA 2001;98: 13925-13930.

-149 Rein A, McClure MR, Rice NR, Luftig RB, Schultz AM: Myristylation site in Pr65gag is essential for virus particle formation by Moloney murine leukemia virus. Proc Natl Acad Sci USA 1986;83:7246-7250.

-150 Schultz AM, Rein A: Unmyristylated Moloney murine leukemia virus Pr65gag is excluded from virus assembly and maturation events. J Virol 1989;63:2370-2373.

-151 Yuan B, Campbell S, Bacharach E, Rein A, Goff SP: Infectivity of Moloney murine leukemia virus defective in late assembly events is restored by late assembly domains of other retroviruses. J Virol 2000;74:72507260 .

-152 Gottlinger HG, Dorfman T, Sodroski JG, Haseltine WA: Effect of mutations affecting the p6 gag protein on human immunodeficiency virus particle release. Proc Natl Acad Sci USA 1991;88:3195-3199.

- 153 King JA, Bridger JM, Gounari F, Lichter P, Schulz TF, Schirrmacher V, Khazaie K: The extended packaging sequence of MoMLV contains a constitutive mRNA nuclear export function. FEBS Lett 1998;434:367-371.

154 Camus G, Segura-Morales C, Molle D, Lopez-Verges S, Begon-Pescia C, Cazevieille C, Schu P, Bertrand E, Berlioz-Torrent C, Basyuk E: The clathrin adaptor complex AP-1 binds HIV-1 and MLV Gag and facilitates their budding. Mol Biol Cell 2007;18: 3193-3203.

-155 Martin-Serrano J, Yarovoy A, Perez-Caballero D, Bieniasz PD: Divergent retroviral late-budding domains recruit vacuolar protein sorting factors by using alternative adaptor proteins. Proc Natl Acad Sci USA 2003;100:12414-12419.

-156 Martin-Serrano J, Zang T, Bieniasz PD: Role of ESCRT-I in retroviral budding. J Virol 2003;77:4794-4804.

-157 Zhadina M, McClure MO, Johnson MC, Bieniasz PD: Ubiquitin-dependent virus particle budding without viral protein ubiquitination. Proc Natl Acad Sci USA 2007;104:20031-20036.

-158 Huang AS, Palma EL, Hewlett N, Roizman B: Pseudotype formation between enveloped RNA and DNA viruses. Nature 1974; 252:743-745.
159 Zavada J: Pseudotypes of vesicular stomatitis virus with the coat of murine leukaemia and of avian myeloblastosis viruses. J Gen Virol 1972;15:183-191.

160 Arthur LO, Bess JW Jr, Sowder RC 2nd, Benveniste RE, Mann DL, Chermann JC, Henderson LE: Cellular proteins bound to immunodeficiency viruses: implications for pathogenesis and vaccines. Science 1992;258:1935-1938.

161 Cantin R, Fortin JF, Lamontagne G, Tremblay $\mathrm{M}$ : The acquisition of host-derived major histocompatibility complex class II glycoproteins by human immunodeficiency virus type 1 accelerates the process of virus entry and infection in human T-lymphoid cells. Blood 1997;90:1091-1100.

162 Fortin JF, Cantin R, Lamontagne G, Tremblay M: Host-derived ICAM-1 glycoproteins incorporated on human immunodeficiency virus type 1 are biologically active and enhance viral infectivity. J Virol 1997; 71:3588-3596.

163 Spear GT, Lurain NS, Parker CJ, Ghassemi M, Payne GH, Saifuddin M: Host cell-derived complement control proteins CD55 and CD59 are incorporated into the virions of two unrelated enveloped viruses: human $\mathrm{T}$ cell leukemia/lymphoma virus type I (HTLV-I) and human cytomegalovirus (HCMV). J Immunol 1995; 155:4376-4381.

164 Young JA, Bates P, Willert K, Varmus HE: Efficient incorporation of human CD4 protein into avian leukosis virus particles. Science 1990;250:1421-1423.

165 Pfistershammer K, Klauser C, Pickl WF, Stockl J, Leitner J, Zlabinger G, Majdic O, Steinberger P: No evidence for dualism in function and receptors: PD-L2/B7-DC is an inhibitory regulator of human $\mathrm{T}$ cell activation. Eur J Immunol 2006;36:1104-1113.

166 Thery C, Zitvogel L, Amigorena S: Exosomes: composition, biogenesis and function. Nat Rev Immunol 2002;2:569-579.

167 van Niel G, Porto-Carreiro I, Simoes S, Raposo G: Exosomes: a common pathway for a specialized function. J Biochem 2006;140: 13-21.

168 Malek TR: The biology of interleukin-2. Annu Rev Immunol 2008;26:453-479.

169 Malek TR, Bayer AL: Tolerance, not immunity, crucially depends on IL-2. Nat Rev Immunol 2004;4:665-674.

170 Waldmann TA: The biology of interleukin-2 and interleukin-15: implications for cancer therapy and vaccine design. Nat Rev Immunol 2006;6:595-601

171 Zhou LJ, Tedder TF: CD14+ blood monocytes can differentiate into functionally mature CD83+ dendritic cells. Proc Natl Acad Sci USA 1996;93:2588-2592.

172 Pandiyan P, Zheng L, Ishihara S, Reed J, Lenardo MJ: CD4+CD25+Foxp3+ regulatory $\mathrm{T}$ cells induce cytokine deprivation-mediated apoptosis of effector CD4+ T cells. Nat Immunol 2007;8:1353-1362.
173 Eren E, Yates J, Cwynarski K, Preston S, Dong R, Germain C, Lechler R, Huby R, Ritter M, Lombardi G: Location of major histocompatibility complex class II molecules in rafts on dendritic cells enhances the efficiency of T-cell activation and proliferation. Scand J Immunol 2006;63:7-16.

174 Hiltbold EM, Poloso NJ, Roche PA: MHC class II-peptide complexes and APC lipid rafts accumulate at the immunological synapse. J Immunol 2003;170:1329-1338.

175 Abdel Motal UM, Sentman CL, Zhou X, Robinson PJ, Dahmen J, Jondal M: Glycosylphosphatidylinositol-linked $\mathrm{Db}$ does not induce an influenza-specific cytotoxic $\mathrm{T}$ lymphocyte response or recycle membrane-bound peptides. Eur J Immunol 1995;25:1121-1124.

176 Sentman CL, Olsson-Alheim MY, Lendahl U, Karre K: Influence of glycosylphosphatidylinositol-linked H-2Dd molecules on target cell protection and natural killer cell specificity in transgenic mice. Eur J Immunol 1996;26:2127-2132.

177 Derdak SV: Immunosomes - T Cell Stimulation by Novel Multi-Purpose AntigenPresenting Platforms; thesis, Medical University of Vienna, 2003.

178 Pircher H, Burki K, Lang R, Hengartner H, Zinkernagel RM: Tolerance induction in double specific T-cell receptor transgenic mice varies with antigen. Nature 1989;342: $559-561$.

179 Betts MR, Brenchley JM, Price DA, De Rosa SC, Douek DC, Roederer M, Koup RA: Sensitive and viable identification of antigenspecific CD8+ T cells by a flow cytometric assay for degranulation. J Immunol Methods 2003;281:65-78.

180 Riddell SR: Finding a place for tumor-specific $\mathrm{T}$ cells in targeted cancer therapy. J Exp Med 2004;200:1533-1537.

$>181$ Riddell SR, Greenberg PD: Principles for adoptive $\mathrm{T}$ cell therapy of human viral diseases. Annu Rev Immunol 1995;13:545586.

182 Rosenberg SA: Immunotherapy and gene therapy of cancer. Cancer Res 1991;51: 5074s-5079s.

183 Ostrand-Rosenberg S: CD4+ T lymphocytes: a critical component of antitumor immunity. Cancer Invest 2005;23:413-419.

184 Gascan H, Gauchat JF, Aversa G, Van Vlasselaer P, de Vries JE: Anti-CD40 monoclonal antibodies or CD4+ $\mathrm{T}$ cell clones and IL-4 induce IgG4 and IgE switching in purified human B cells via different signaling pathways. J Immunol 1991;147:8-13.

185 Gascan H, Gauchat JF, Roncarolo MG, Yssel H, Spits H, de Vries JE: Human B cell clones can be induced to proliferate and to switch to IgE and IgG4 synthesis by interleukin 4 and a signal provided by activated CD4+ T cell clones. J Exp Med 1991;173: $747-750$ 
186 Geha RS, Schneeberger E, Rosen FS, Merler E: Interaction of human thymus-derived and non-thymus-derived lymphocytes in vitro. Induction of proliferation and antibody synthesis in B lymphocytes by a soluble factor released from antigen-stimulated T lymphocytes. J Exp Med 1973;138:12301247.

$\checkmark 187$ Coffman RL, Carty J: A T cell activity that enhances polyclonal IgE production and its inhibition by interferon-gamma. J Immunol 1986;136:949-954.

188 Romagnani S: Immunologic influences on allergy and the TH1/TH2 balance. J Allergy Clin Immunol 2004;113:395-400.

- 189 Bettelli E, Korn T, Oukka M, Kuchroo VK: Induction and effector functions of $\mathrm{T}(\mathrm{H}) 17$ cells. Nature 2008;453:1051-1057.

190 Park H, Li Z, Yang XO, Chang SH, Nurieva R, Wang YH, Wang Y, Hood L, Zhu Z, Tian Q, Dong C: A distinct lineage of CD4 T cells regulates tissue inflammation by producing interleukin 17. Nat Immunol 2005;6: 1133-1141.

-191 Gershon RK, Kondo K: Infectious immunological tolerance. Immunology 1971;21: 903-914.

192 Groux H, O’Garra A, Bigler M, Rouleau M, Antonenko S, de Vries JE, Roncarolo MG: A CD4+ T-cell subset inhibits antigen-specific T-cell responses and prevents colitis. Nature 1997;389:737-742.

193 Sakaguchi S, Sakaguchi N, Asano M, Itoh M, Toda M: Immunologic self-tolerance maintained by activated $\mathrm{T}$ cells expressing IL-2 receptor alpha-chains (CD25): breakdown of a single mechanism of self-tolerance causes various autoimmune diseases. J Immunol 1995;155:1151-1164.

-194 Weiner HL: The mucosal milieu creates tolerogenic dendritic cells and $\mathrm{T}(\mathrm{R}) 1$ and $\mathrm{T}(\mathrm{H}) 3$ regulatory cells. Nat Immunol 2001; 2:671-672.

-195 Jiang S, Lechler RI: CD4+CD25+ regulatory T-cell therapy for allergy, autoimmune disease and transplant rejection. Inflamm Allergy Drug Targets 2006;5:239-242.

196 Saloga J, Bellinghausen I, Knop J: Do Tr1 cells play a role in immunotherapy? Int Arch Allergy Immunol 1999;118:210-211.

-197 Himly M, Jahn-Schmid B, Dedic A, Kelemen P, Wopfner N, Altmann F, van Ree R, Briza P, Richter K, Ebner C, Ferreira F: Art $\mathrm{v} 1$, the major allergen of mugwort pollen, is a modular glycoprotein with a defensinlike and a hydroxyproline-rich domain. FASEB J 2003;17:106-108.

198 Jahn-Schmid B, Fischer GF, Bohle B, Fae I, Gadermaier G, Dedic A, Ferreira F, Ebner $\mathrm{C}$ : Antigen presentation of the immunodominant T-cell epitope of the major mugwort pollen allergen, Art v 1, is associated with the expression of HLA-DRB1 *01. J Allergy Clin Immunol 2005;115:399-404.
199 Jahn-Schmid B, Kelemen P, Himly M, Bohle B, Fischer G, Ferreira F, Ebner C: The T cell response to Art v 1, the major mugwort pollen allergen, is dominated by one epitope. J Immunol 2002;169:6005-6011.

200 Jahn-Schmid B, Sirven P, Leb V, Pickl WF, Fischer GF, Gadermaier G, Egger M, Ebner C, Ferreira F, Maillere B, Bohle B: Characterization of HLA class II/peptide-TCR interactions of the immunodominant $\mathrm{T}$ cell epitope in Art v 1, the major mugwort pollen allergen. J Immunol 2008;181:36363642 .

201 van Bergen J, Schoenberger SP, Verreck F, Amons R, Offringa R, Koning F: Efficient loading of HLA-DR with a T helper epitope by genetic exchange of CLIP. Proc Natl Acad Sci USA 1997;94:7499-7502.

202 Gimmi CD, Freeman GJ, Gribben JG, Gray G, Nadler LM: Human T-cell clonal anergy is induced by antigen presentation in the absence of B7 costimulation. Proc Natl Acad Sci USA 1993;90:6586-6590.

203 Schwartz RH: A cell culture model for T lymphocyte clonal anergy. Science 1990; 248:1349-1356.

204 Dalai SK, Mirshahidi S, Morrot A, Zavala F, Sadegh-Nasseri S: Anergy in memory $\mathrm{CD} 4+\mathrm{T}$ cells is induced by B cells. J Immunol 2008; 181:3221-3231.

-205 Dure M, Macian F: IL-2 signaling prevents T cell anergy by inhibiting the expression of anergy-inducing genes. Mol Immunol 2009;46:999-1006.

206 Macian F, Garcia-Cozar F, Im SH, Horton HF, Byrne MC, Rao A: Transcriptional mechanisms underlying lymphocyte tolerance. Cell 2002;109:719-731.

207 Zha Y, Marks R, Ho AW, Peterson AC, Janardhan S, Brown I, Praveen K, Stang S, Stone JC, Gajewski TF: T cell anergy is reversed by active Ras and is regulated by diacylglycerol kinase-alpha. Nat Immunol 2006;7:1166-1173.

208 Lanier LL, O’Fallon S, Somoza C, Phillips JH, Linsley PS, Okumura K, Ito D, Azuma M: CD80 (B7) and CD86 (B70) provide similar costimulatory signals for T cell proliferation, cytokine production, and generation of CTL. J Immunol 1995;154:97-105

209 Parra E, Wingren AG, Hedlund G, Bjorklund M, Sjogren HO, Kalland T, Sansom D, Dohlsten M: Costimulation of human CD4+ T lymphocytes with B7 and lymphocyte function-associated antigen-3 results in distinct cell activation profiles. J Immunol 1994;153:2479-2487.

210 Wakkach A, Cottrez F, Groux H: Differentiation of regulatory $\mathrm{T}$ cells 1 is induced by CD2 costimulation. J Immunol 2001;167: 3107-3113.

211 Akdis CA, Blesken T, Akdis M, Wuthrich B, Blaser K: Role of interleukin 10 in specific immunotherapy. J Clin Invest 1998;102:98106.
212 Bellinghausen I, Metz G, Enk AH, Christmann S, Knop J, Saloga J: Insect venom immunotherapy induces interleukin-10 production and a Th2-to-Th1 shift, and changes surface marker expression in venom-allergic subjects. Eur J Immunol 1997; 27:1131-1139.

213 Jutel M, Pichler WJ, Skrbic D, Urwyler A, Dahinden C, Muller UR: Bee venom immunotherapy results in decrease of IL- 4 and IL-5 and increase of IFN-gamma secretion in specific allergen-stimulated T cell cultures. J Immunol 1995;154:4187-4194.

214 Kemper C, Chan AC, Green JM, Brett KA, Murphy KM, Atkinson JP: Activation of human CD4+ cells with CD3 and CD46 induces a T-regulatory cell 1 phenotype. Nature 2003;421:388-392.

215 Murugaiyan G, Mittal A, Lopez-Diego R, Maier LM, Anderson DE, Weiner HL: IL-27 is a key regulator of IL-10 and IL-17 production by human CD4+ T cells. J Immunol 2009; 183:2435-2443.

216 Tax WJ, Hermes FF, Willems RW, Capel PJ, Koene RA: Fc receptors for mouse IgG1 on human monocytes: polymorphism and role in antibody-induced T cell proliferation. J Immunol 1984;133:1185-1189.

217 Fewtrell C, Metzger H: Larger oligomers of IgE are more effective than dimers in stimulating rat basophilic leukemia cells. J Immunol 1980;125:701-710.

-218 Minguet S, Swamy M, Alarcon B, Luescher IF, Schamel WW: Full activation of the T cell receptor requires both clustering and conformational changes at CD3. Immunity 2007;26:43-54.

219 Mossman KD, Campi G, Groves JT, Dustin ML: Altered TCR signaling from geometrically repatterned immunological synapses. Science 2005;310:1191-1193.

220 Ratcliffe MJ, Coggeshall KM, Newell MK, Julius MH: T cell receptor aggregation, but not dimerization, induces increased cytosolic calcium concentrations and reveals a lack of stable association between CD4 and the T cell receptor. J Immunol 1992;148: 1643-1651.

221 Torigoe C, Inman JK, Metzger H: An unusual mechanism for ligand antagonism. Science 1998;281:568-572

222 Grakoui A, Bromley SK, Sumen C, Davis MM, Shaw AS, Allen PM, Dustin ML: The immunological synapse: a molecular machine controlling $\mathrm{T}$ cell activation. Science 1999;285:221-227.

-223 Hafeman DG, von Tscharner V, McConnell HM: Specific antibody-dependent interactions between macrophages and lipid haptens in planar lipid monolayers. Proc Natl Acad Sci USA 1981;78:4552-4556.

224 Groves JT, Dustin ML: Supported planar bilayers in studies on immune cell adhesion and communication. J Immunol Methods 2003;278:19-32. 
225 McConnell HM, Watts TH, Weis RM, Brian AA: Supported planar membranes in studies of cell-cell recognition in the immune system. Biochim Biophys Acta 1986; 864:95-106

-226 Groves JT, Boxer SG: Micropattern formation in supported lipid membranes. Acc Chem Res 2002;35:149-157.

-227 Sackmann E: Supported membranes: scientific and practical applications. Science 1996;271:43-48.

-228 Medof ME, Nagarajan S, Tykocinski ML: Cell-surface engineering with GPI-anchored proteins. FASEB J 1996;10:574-586.

-229 Metzner C, Salmons B, Gunzburg WH, Dangerfield JA: Rafts, anchors and viruses - a role for glycosylphosphatidylinositol anchored proteins in the modification of enveloped viruses and viral vectors. Virology 2008;382:125-131.

-230 Herrmann SH, Weinberger O, Burakoff SJ, Mescher MF: Analysis of the two-signal requirement for precursor cytolytic T lymphocyte activation using $\mathrm{H}-2 \mathrm{Kk}$ in liposomes. J Immunol 1982;128:1968-1974.

-231 Mescher MF: Surface contact requirements for activation of cytotoxic T lymphocytes. J Immunol 1992;149:2402-2405.

-232 Prakken B, Wauben M, Genini D, Samodal R, Barnett J, Mendivil A, Leoni L, Albani S: Artificial antigen-presenting cells as a tool to exploit the immune 'synapse'. Nat Med 2000;6:1406-1410.

-233 Levine BL, Bernstein WB, Connors M, Craighead N, Lindsten T, Thompson CB, June CH: Effects of CD28 costimulation on long-term proliferation of CD4+ T cells in the absence of exogenous feeder cells. J Immunol 1997;159:5921-5930.

234 Levine BL, Bernstein WB, Aronson NE, Schlienger K, Cotte J, Perfetto S, Humphries MJ, Ratto-Kim S, Birx DL, Steffens C, Landay A, Carroll RG, June $\mathrm{CH}$ : Adoptive transfer of costimulated CD4+ T cells induces expansion of peripheral $\mathrm{T}$ cells and decreased CCR5 expression in HIV infection. Nat Med 2002;8:47-53.

-235 Rieu S, Geminard C, Rabesandratana H, Sainte-Marie J, Vidal M: Exosomes released during reticulocyte maturation bind to fibronectin via integrin alpha4beta1. Eur J Biochem 2000;267:583-590.

-236 van Niel G, Raposo G, Candalh C, Boussac M, Hershberg R, Cerf-Bensussan N, Heyman $\mathrm{M}$ : Intestinal epithelial cells secrete exosome-like vesicles. Gastroenterology 2001;121:337-349.

-237 Faure J, Lachenal G, Court M, Hirrlinger J, Chatellard-Causse C, Blot B, Grange J, Schoehn G, Goldberg Y, Boyer V, Kirchhoff F, Raposo G, Garin J, Sadoul R: Exosomes are released by cultured cortical neurones. Mol Cell Neurosci 2006;31:642-648.
238 Raposo G, Nijman HW, Stoorvogel W, Liejendekker R, Harding CV, Melief CJ, Geuze HJ: B lymphocytes secrete antigenpresenting vesicles. J Exp Med 1996;183: 1161-1172.

239 Blanchard N, Lankar D, Faure F, Regnault A, Dumont C, Raposo G, Hivroz C: TCR activation of human T cells induces the production of exosomes bearing the TCR/ CD3/zeta complex. J Immunol 2002;168: 3235-3241.

240 Skokos D, Le Panse S, Villa I, Rousselle JC, Peronet R, David B, Namane A, Mecheri S: Mast cell-dependent B and T lymphocyte activation is mediated by the secretion of immunologically active exosomes. J Immunol 2001;166:868-876.

241 Zitvogel L, Regnault A, Lozier A, Wolfers J, Flament C, Tenza D, Ricciardi-Castagnoli P, Raposo G, Amigorena S: Eradication of established murine tumors using a novel cell-free vaccine: dendritic cell-derived exosomes. Nat Med 1998;4:594-600.

242 Wolfers J, Lozier A, Raposo G, Regnault A, Thery C, Masurier C, Flament C, Pouzieux S, Faure F, Tursz T, Angevin E, Amigorena S, Zitvogel L: Tumor-derived exosomes are a source of shared tumor rejection antigens for CTL cross-priming. Nat Med 2001;7: 297-303.

243 Blanc L, De Gassart A, Geminard C, BetteBobillo P, Vidal M: Exosome release by reticulocytes - an integral part of the red blood cell differentiation system. Blood Cells Mol Dis 2005;35:21-26.

244 Liu S, Stolz DB, Sappington PL, Macias CA Killeen ME, Tenhunen JJ, Delude RL, Fink MP: HMGB1 is secreted by immunostimulated enterocytes and contributes to cytomix-induced hyperpermeability of Caco-2 monolayers. Am J Physiol Cell Physiol 2006;290:C990-C999.

245 Segura E, Nicco C, Lombard B, Veron P, Raposo G, Batteux F, Amigorena S, Thery C: ICAM-1 on exosomes from mature dendritic cells is critical for efficient naive Tcell priming. Blood 2005;106:216-223.

246 Thery C, Duban L, Segura E, Veron P, Lantz $\mathrm{O}$, Amigorena S: Indirect activation of naive CD4+ T cells by dendritic cell-derived exosomes. Nat Immunol 2002;3:1156-1162.

247 Vincent-Schneider H, Stumptner-Cuvelette P, Lankar D, Pain S, Raposo G, Benaroch $\mathrm{P}$, Bonnerot $\mathrm{C}$ : Exosomes bearing HLA-DR1 molecules need dendritic cells to efficiently stimulate specific T cells. Int Immunol 2002;14:713-722.

248 Admyre C, Johansson SM, Paulie S, Gabrielsson S: Direct exosome stimulation of peripheral human $\mathrm{T}$ cells detected by ELISPOT. Eur J Immunol 2006;36:17721781.
249 Admyre C, Bohle B, Johansson SM, FockeTejkl M, Valenta R, Scheynius A, Gabrielsson S: B cell-derived exosomes can present allergen peptides and activate allergen-specific T cells to proliferate and produce TH2like cytokines. J Allergy Clin Immunol 2007;120:1418-1424.

250 Bender A, Sapp M, Schuler G, Steinman RM, Bhardwaj N: Improved methods for the generation of dendritic cells from nonproliferating progenitors in human blood. J Immunol Methods 1996;196:121-135.

251 Lutz MB, Kukutsch N, Ogilvie AL, Rossner S, Koch F, Romani N, Schuler G: An advanced culture method for generating large quantities of highly pure dendritic cells from mouse bone marrow. J Immunol Methods 1999;223:77-92.

252 Nestle FO, Alijagic S, Gilliet M, Sun Y, Grabbe S, Dummer R, Burg G, Schadendorf D: Vaccination of melanoma patients with peptide- or tumor lysate-pulsed dendritic cells. Nat Med 1998;4:328-332.

253 Palucka AK, Ueno H, Fay J, Banchereau J: Dendritic cells: a critical player in cancer therapy? J Immunother 2008;31:793-805.

254 Rubio MT, Ittelet D, Raymond E, Blay JY, Bernard J, Chouaib S: The immunosuppressive effect of vincristine on allostimulatory potential of human dendritic cells interferes with their function and survival. Int J Oncol 2004;25:407-412.

255 Steinman RM, Hawiger D, Nussenzweig MC: Tolerogenic dendritic cells. Annu Rev Immunol 2003;21:685-711.

256 Adorini L, Penna G: Induction of tolerogenic dendritic cells by vitamin $\mathrm{D}$ receptor agonists. Handb Exp Pharmacol 2009;188: 251-273.

257 Buckland M, Lombardi G: Aspirin and the induction of tolerance by dendritic cells. Handb Exp Pharmacol 2009;188:197-213.

258 Fischer R, Turnquist HR, Taner T, Thomson AW: Use of rapamycin in the induction of tolerogenic dendritic cells. Handb Exp Pharmacol 2009;188:215-232.

259 van Kooten C, Stax AS, Woltman AM, Gelderman KA: Handbook of experimental pharmacology 'dendritic cells': the use of dexamethasone in the induction of tolerogenic DCs. Handb Exp Pharmacol 2009; 188:233-249.

260 Jonuleit H, Schmitt E, Schuler G, Knop J, Enk AH: Induction of interleukin 10-producing, nonproliferating CD4(+) $\mathrm{T}$ cells with regulatory properties by repetitive stimulation with allogeneic immature human dendritic cells. J Exp Med 2000;192: 1213-1222.

-261 Sato K, Yamashita N, Baba M, Matsuyama T: Modified myeloid dendritic cells act as regulatory dendritic cells to induce anergic and regulatory $\mathrm{T}$ cells. Blood 2003;101: 3581-3589. 
262 Bellinghausen I, Konig B, Bottcher I, Knop J, Saloga J: Inhibition of human allergic Thelper type 2 immune responses by induced regulatory $\mathrm{T}$ cells requires the combination of interleukin-10-treated dendritic cells and transforming growth factor-beta for their induction. Clin Exp Allergy 2006;36: 1546-1555.

263 Maloy KJ, Powrie F: Regulatory T cells in the control of immune pathology. Nat Immunol 2001;2:816-822.

-264 Thunberg S, Akdis M, Akdis CA, Gronneberg R, Malmstrom V, Trollmo C, van Hage $\mathrm{M}$, Gafvelin G: Immune regulation by CD4+CD25+ T cells and interleukin-10 in birch pollen-allergic patients and non-allergic controls. Clin Exp Allergy 2007;37: 1127-1136.

-265 Kim SH, Lechman ER, Bianco N, Menon R, Keravala A, Nash J, Mi Z, Watkins SC, Gambotto A, Robbins PD: Exosomes derived from IL-10-treated dendritic cells can suppress inflammation and collagen-induced arthritis. J Immunol 2005; 174:64406448.

266 Bianco NR, Kim SH, Ruffner MA, Robbins PD: Therapeutic effect of exosomes from indoleamine 2,3-dioxygenase-positive dendritic cells in collagen-induced arthritis and delayed-type hypersensitivity disease models. Arthritis Rheum 2009;60:380-389.

-267 Muller B, Daecke J, Fackler OT, Dittmar MT, Zentgraf H, Krausslich HG: Construction and characterization of a fluorescently labeled infectious human immunodeficiency virus type 1 derivative. J Virol 2004; 78:10803-10813.

-268 Stauber RH, Rulong S, Palm G, Tarasova NI: Direct visualization of HIV-1 entry: mechanisms and role of cell surface receptors. Biochem Biophys Res Commun 1999; 258:695-702.

-269 Yasuda K, Kosugi A, Hayashi F, Saitoh S, Nagafuku M, Mori Y, Ogata M, Hamaoka T: Serine 6 of Lck tyrosine kinase: a critical site for Lck myristoylation, membrane localization, and function in $\mathrm{T}$ lymphocytes. J Immunol 2000;165:3226-3231.

-270 Zhou W, Parent LJ, Wills JW, Resh MD: Identification of a membrane-binding domain within the amino-terminal region of human immunodeficiency virus type $1 \mathrm{Gag}$ protein which interacts with acidic phospholipids. J Virol 1994;68:2556-2569.

271 Li H, Dou J, Ding L, Spearman P: Myristoylation is required for human immunodeficiency virus type $1 \mathrm{Gag}$-Gag multimerization in mammalian cells. J Virol 2007;81: 12899-12910.

272 Thankamony SP, Knudson W: Acylation of CD44 and its association with lipid rafts are required for receptor and hyaluronan endocytosis. J Biol Chem 2006;281:3460134609 .
273 Zhang W, Trible RP, Samelson LE: LAT palmitoylation: its essential role in membrane microdomain targeting and tyrosine phosphorylation during $\mathrm{T}$ cell activation. Immunity 1998;9:239-246.

274 Parenti M, Vigano MA, Newman CM, Milligan G, Magee AI: A novel N-terminal motif for palmitoylation of G-protein alpha subunits. Biochem J 1993;291(pt 2):349353.

275 Kabouridis PS, Magee AI, Ley SC: S-acylation of LCK protein tyrosine kinase is essential for its signalling function in T lymphocytes. EMBO J 1997;16:4983-4998.

276 Luetterforst R, Stang E, Zorzi N, Carozzi A Way M, Parton RG: Molecular characterization of caveolin association with the Golgi complex: identification of a cis-Golgi targeting domain in the caveolin molecule. J Cell Biol 1999;145:1443-1459.

277 Chen BJ, Takeda M, Lamb RA: Influenza virus hemagglutinin ( $\mathrm{H} 3$ subtype) requires palmitoylation of its cytoplasmic tail for assembly: M1 proteins of two subtypes differ in their ability to support assembly. J Virol 2005;79:13673-13684.

278 Chakrabandhu K, Herincs Z, Huault S, Dost B, Peng L, Conchonaud F, Marguet D, He HT, Hueber AO: Palmitoylation is required for efficient Fas cell death signaling. EMBO J 2007;26:209-220.

279 Ziegler-Heitbrock HW, Ulevitch RJ: CD14: cell surface receptor and differentiation marker. Immunol Today 1993;14:121-125.

280 Ravetch JV, Perussia B: Alternative membrane forms of Fc gamma RIII(CD16) on human natural killer cells and neutrophils: cell type-specific expression of two genes that differ in single nucleotide substitutions. J Exp Med 1989;170:481-497.

-281 Selvaraj P, Rosse WF, Silber R, Springer TA: The major Fc receptor in blood has a phosphatidylinositol anchor and is deficient in paroxysmal nocturnal haemoglobinuria. Nature 1988;333:565-567.

282 Classon BJ, Williams AF, Willis AC, Seed B, Stamenkovic I: The primary structure of the human leukocyte antigen CD37, a species homologue of the rat MRC OX-44 antigen. J Exp Med 1989;169:1497-1502.

283 Amiot M: Identification and analysis of cDNA clones encoding CD53: a pan-leukocyte antigen related to membrane transport proteins. J Immunol 1990;145:4322-4325.

284 Selvaraj P, Dustin ML, Silber R, Low MG, Springer TA: Deficiency of lymphocyte function-associated antigen 3 (LFA-3) in paroxysmal nocturnal hemoglobinuria: functional correlates and evidence for a phosphatidylinositol membrane anchor. J Exp Med 1987;166:1011-1025.
285 Porter JA, Ekker SC, Park WJ, von Kessler DP, Young KE, Chen CH, Ma Y, Woods AS, Cotter RJ, Koonin EV, Beachy PA: Hedgehog patterning activity: role of a lipophilic modification mediated by the carboxy-terminal autoprocessing domain. Cell 1996; 86:21-34.

286 Porter JA, Young KE, Beachy PA: Cholesterol modification of hedgehog signaling proteins in animal development. Science 1996;274:255-259.

287 Mann RK, Beachy PA: Cholesterol modification of proteins. Biochim Biophys Acta 2000;1529:188-202.

288 Karpen HE, Bukowski JT, Hughes T, Gratton JP, Sessa WC, Gailani MR: The sonic hedgehog receptor patched associates with caveolin-1 in cholesterol-rich microdomains of the plasma membrane. J Biol Chem 2001;276:19503-19511.

289 Beekman JM, Bakema JE, van de Winkel JG, Leusen JH: Direct interaction between FcgammaRI (CD64) and periplakin controls receptor endocytosis and ligand binding capacity. Proc Natl Acad Sci USA 2004; 101:10392-10397.

290 Langhorst MF, Reuter A, Stuermer CA: Scaffolding microdomains and beyond: the function of reggie/flotillin proteins. Cell Mol Life Sci 2005;62:2228-2240.

-291 Parton RG, Hanzal-Bayer M, Hancock JF: Biogenesis of caveolae: a structural model for caveolin-induced domain formation. J Cell Sci 2006;119:787-796.

292 Beekman JM, van der Linden JA, van de Winkel JG, Leusen JH: FcgammaRI (CD64) resides constitutively in lipid rafts. Immunol Lett 2008;116:149-155.

293 Li H, Papadopoulos V: Peripheral-type benzodiazepine receptor function in cholesterol transport: identification of a putative cholesterol recognition/interaction amino acid sequence and consensus pattern. Endocrinology 1998;139:4991-4997.

294 Palmer M: Cholesterol and the activity of bacterial toxins. FEMS Microbiol Lett 2004;238:281-289.

295 Li H, Yao Z, Degenhardt B, Teper G, Papadopoulos V: Cholesterol binding at the cholesterol recognition/interaction amino acid consensus (CRAC) of the peripheral-type benzodiazepine receptor and inhibition of steroidogenesis by an HIV TAT-CRAC peptide. Proc Natl Acad Sci USA 2001;98: $1267-1272$.

296 Jamin N, Neumann JM, Ostuni MA, Vu TK, Yao ZX, Murail S, Robert JC, Giatzakis C, Papadopoulos V, Lacapere JJ: Characterization of the cholesterol recognition amino acid consensus sequence of the peripheral-type benzodiazepine receptor. Mol Endocrinol 2005;19:588-594.

-297 Takimoto T, Portner A: Molecular mechanism of paramyxovirus budding. Virus Res 2004;106:133-145. 
298 Pantua HD, McGinnes LW, Peeples ME, Morrison TG: Requirements for the assembly and release of Newcastle disease viruslike particles. J Virol 2006;80:11062-11073.

-299 Shnyrova AV, Ayllon J, Mikhalyov II, Villar E, Zimmerberg J, Frolov VA: Vesicle formation by self-assembly of membrane-bound matrix proteins into a fluidlike budding domain. J Cell Biol 2007;179:627-633.

\$300 McCurdy LH, Graham BS: Role of plasma membrane lipid microdomains in respiratory syncytial virus filament formation. J Virol 2003;77:1747-1756.

>301 Marty A, Meanger J, Mills J, Shields B, Ghildyal R: Association of matrix protein of respiratory syncytial virus with the host cell membrane of infected cells. Arch Virol 2004;149:199-210.

>302 Fleming EH, Kolokoltsov AA, Davey RA, Nichols JE, Roberts NJ Jr: Respiratory syncytial virus $\mathrm{F}$ envelope protein associates with lipid rafts without a requirement for other virus proteins. J Virol 2006;80:1216012170.

303 Oomens AG, Bevis KP, Wertz GW: The cytoplasmic tail of the human respiratory syncytial virus $\mathrm{F}$ protein plays critical roles in cellular localization of the F protein and infectious progeny production. J Virol 2006;80:10465-10477.

>304 Batonick M, Oomens AG, Wertz GW: Human respiratory syncytial virus glycoproteins are not required for apical targeting and release from polarized epithelial cells. J Virol 2008;82:8664-8672.

>305 Pohl C, Duprex WP, Krohne G, Rima BK, Schneider-Schaulies S: Measles virus M and $\mathrm{F}$ proteins associate with detergent-resistant membrane fractions and promote formation of virus-like particles. J Gen Virol 2007;88:1243-1250

>306 Takimoto T, Murti KG, Bousse T, Scroggs RA, Portner A: Role of matrix and fusion proteins in budding of Sendai virus. J Virol 2001;75:11384-11391.

-307 Schmitt AP, Leser GP, Waning DL, Lamb RA: Requirements for budding of paramyxovirus simian virus 5 virus-like particles. J Virol 2002;76:3952-3964.

-308 Gosselin-Grenet AS, Mottet-Osman G, Roux L: From assembly to virus particle budding: pertinence of the detergent resistant membranes. Virology 2006;344:296303.

-309 Irie T, Nagata N, Yoshida T, Sakaguchi T: Recruitment of Alix/AIP1 to the plasma membrane by Sendai virus $C$ protein facilitates budding of virus-like particles. Virology 2008;371:108-120.

$\$ 310$ Brown EL, Lyles DS: Organization of the vesicular stomatitis virus glycoprotein into membrane microdomains occurs independently of intracellular viral components. J Virol 2003;77:3985-3992.
311 Irie T, Licata JM, Jayakar HR, Whitt MA, Bell P, Harty RN: Functional analysis of late-budding domain activity associated with the PSAP motif within the vesicular stomatitis virus M protein. J Virol 2004;78: 7823-7827.

312 Swinteck BD, Lyles DS: Plasma membrane microdomains containing vesicular stomatitis virus $M$ protein are separate from $\mathrm{mi}$ crodomains containing $\mathrm{G}$ protein and nucleocapsids. J Virol 2008;82:5536-5547.

-313 Bavari S, Bosio CM, Wiegand E, Ruthel G, Will AB, Geisbert TW, Hevey M, Schmaljohn C, Schmaljohn A, Aman MJ: Lipid raft microdomains: a gateway for compartmentalized trafficking of Ebola and Marburg viruses. J Exp Med 2002;195:593-602.

314 Kolesnikova L, Berghofer B, Bamberg S, Becker S: Multivesicular bodies as a platform for formation of the Marburg virus envelope. J Virol 2004;78:12277-12287.

315 Kolesnikova L, Strecker T, Morita E, Zielecki F, Mittler E, Crump C, Becker S: Vacuolar protein sorting pathway contributes to the release of Marburg virus. J Virol 2009;83:2327-2337.

316 Freed EO: Virology: rafting with Ebola. Science $2002 ; 296: 279$

317 Aman MJ, Bosio CM, Panchal RG, Burnett JC, Schmaljohn A, Bavari S: Molecular mechanisms of filovirus cellular trafficking. Microbes Infect 2003;5:639-649.

318 Dolnik O, Kolesnikova L, Becker S: Filoviruses: interactions with the host cell. Cell Mol Life Sci 2008;65:756-776.

319 Gomez-Puertas P, Albo C, Perez-Pastrana E, Vivo A, Portela A: Influenza virus matrix protein is the major driving force in virus budding. J Virol 2000;74:11538-11547.

320 Leser GP, Lamb RA: Influenza virus assembly and budding in raft-derived microdomains: a quantitative analysis of the surface distribution of HA, NA and M2 proteins. Virology 2005;342:215-227.

-321 Chen BJ, Leser GP, Morita E, Lamb RA: Influenza virus hemagglutinin and neuraminidase, but not the matrix protein, are required for assembly and budding of plasmid-derived virus-like particles. J Virol 2007;81:7111-7123.

322 Radyukhin V, Fedorova N, Ksenofontov A, Serebryakova M, Baratova L: Cold co-extraction of hemagglutinin and matrix M1 protein from influenza virus A by a combination of non-ionic detergents allows for visualization of the raft-like nature of the virus envelope. Arch Virol 2008; 153: 1977-1980.

-323 Henderson LE, Krutzsch HC, Oroszlan S: Myristyl amino-terminal acylation of murine retrovirus proteins: an unusual posttranslational proteins modification. Proc Natl Acad Sci USA 1983;80:339-343.
324 Spearman P, Wang JJ, Vander Heyden N, Ratner L: Identification of human immunodeficiency virus type 1 Gag protein domains essential to membrane binding and particle assembly. J Virol 1994;68:32323242.

325 Morikawa Y, Hinata S, Tomoda H, Goto T, Nakai M, Aizawa C, Tanaka H, Omura S: Complete inhibition of human immunodeficiency virus Gag myristoylation is necessary for inhibition of particle budding. J Biol Chem 1996;271:2868-2873.

326 Bhattacharya J, Repik A, Clapham PR: Gag regulates association of human immunodeficiency virus type 1 envelope with detergent-resistant membranes. J Virol 2006;80: 5292-5300.

327 Urano E, Aoki T, Futahashi Y, Murakami T, Morikawa Y, Yamamoto N, Komano J: Substitution of the myristoylation signal of human immunodeficiency virus type 1 Pr55Gag with the phospholipase C-delta1 pleckstrin homology domain results in infectious pseudovirion production. J Gen Virol 2008;89:3144-3149.

328 Jordan M, Schallhorn A, Wurm FM: Transfecting mammalian cells: optimization of critical parameters affecting calciumphosphate precipitate formation. Nucleic Acids Res 1996;24:596-601.

329 Yu F, Joshi SM, Ma YM, Kingston RL, Simon MN, Vogt VM: Characterization of Rous sarcoma virus Gag particles assembled in vitro. J Virol 2001;75:2753-2764.

-330 Van Wauwe JP, De Mey JR, Goossens JG: OKT3: a monoclonal anti-human T lymphocyte antibody with potent mitogenic properties. J Immunol 1980;124:27082713.

331 Meuer SC, Hodgdon JC, Hussey RE, Protentis JP, Schlossman SF, Reinherz EL: Antigen-like effects of monoclonal antibodies directed at receptors on human $\mathrm{T}$ cell clones. J Exp Med 1983;158:988-993.

332 Riddell SR, Greenberg PD: The use of antiCD3 and anti-CD28 monoclonal antibodies to clone and expand human antigenspecific T cells. J Immunol Methods 1990; 128:189-201.

333 Oelke M, Maus MV, Didiano D, June CH, Mackensen A, Schneck JP: Ex vivo induction and expansion of antigen-specific cytotoxic T cells by HLA-Ig-coated artificial antigen-presenting cells. Nat Med 2003;9: 619-624.

\$33 Maus MV, Riley JL, Kwok WW, Nepom GT, June CH: HLA tetramer-based artificial antigen-presenting cells for stimulation of CD4+ T cells. Clin Immunol 2003;106:1622.

335 Delbrück A: Structural Chemistry and Molecular Biology. 1968:168-215.

>336 Brian AA, McConnell HM: Allogeneic stimulation of cytotoxic T cells by supported planar membranes. Proc Natl Acad Sci USA 1984;81:6159-6163. 
-337 Groves JT, Ulman N, Boxer SG: Micropatterning fluid lipid bilayers on solid supports. Science 1997;275:651-653.

-338 Viaud S, Terme M, Flament C, Taieb J, Andre F, Novault S, Escudier B, Robert C, Caillat-Zucman S, Tursz T, Zitvogel L, Chaput N: Dendritic cell-derived exosomes promote natural killer cell activation and proliferation: a role for NKG2D ligands and IL-15Ralpha. PLoS One 2009; 4:e4942.

>339 Metzner C, Mostegl MM, Gunzburg WH, Salmons B, Dangerfield JA: Association of glycosylphosphatidylinositol-anchored protein with retroviral particles. FASEB J 2008;22:2734-2739.

\340 Dudley ME, Wunderlich JR, Robbins PF, Yang JC, Hwu P, Schwartzentruber DJ, Topalian SL, Sherry R, Restifo NP, Hubicki AM, Robinson MR, Raffeld M, Duray P, Seipp CA, Rogers-Freezer L, Morton KE, Mavroukakis SA, White DE, Rosenberg SA: Cancer regression and autoimmunity in patients after clonal repopulation with antitumor lymphocytes. Science 2002;298: 850-854.

-341 Dudley ME, Rosenberg SA: Adoptive-celltransfer therapy for the treatment of patients with cancer. Nat Rev Cancer 2003;3: 666-675.

-342 Dudley ME, Wunderlich JR, Yang JC, Sherry RM, Topalian SL, Restifo NP, Royal RE, Kammula U, White DE, Mavroukakis SA, Rogers LJ, Gracia GJ, Jones SA, Mangiameli DP, Pelletier MM, Gea-Banacloche J, Robinson MR, Berman DM, Filie AC, Abati A, Rosenberg SA: Adoptive cell transfer therapy following non-myeloablative but lymphodepleting chemotherapy for the treatment of patients with refractory metastatic melanoma. J Clin Oncol 2005;23: 2346-2357.

343 Robinson SP, Stagg AJ: Dendritic Cell Protocols. Humana Totowa, NJ 2001.

344 Davis ID, Jefford M, Parente P, Cebon J: Rational approaches to human cancer immunotherapy. J Leukoc Biol 2003;73:3-29.
345 Gilboa E: DC-based cancer vaccines. J Clin Invest 2007;117:1195-1203.

>346 Banchereau J, Palucka AK, Dhodapkar M, Burkeholder S, Taquet N, Rolland A, Taquet S, Coquery S, Wittkowski KM, Bhardwaj N, Pineiro L, Steinman R, Fay J: Immune and clinical responses in patients with metastatic melanoma to CD34(+) progenitor-derived dendritic cell vaccine. Cancer Res 2001;61:6451-6458.

347 Lu W, Arraes LC, Ferreira WT, Andrieu JM: Therapeutic dendritic-cell vaccine for chronic HIV-1 infection. Nat Med 2004;10: 1359-1365.

348 Palucka AK, Dhodapkar MV, Paczesny S, Ueno H, Fay J, Banchereau J: Boosting vaccinations with peptide-pulsed CD34+ progenitor-derived dendritic cells can expand long-lived melanoma peptide-specific $\mathrm{CD} 8+\mathrm{T}$ cells in patients with metastatic melanoma. J Immunother 2005;28:158168.

349 Fay JW, Palucka AK, Paczesny S, Dhodapkar M, Johnston DA, Burkeholder S, Ueno $\mathrm{H}$, Banchereau J: Long-term outcomes in patients with metastatic melanoma vaccinated with melanoma peptide-pulsed CD34(+) progenitor-derived dendritic cells. Cancer Immunol Immunother 2006; 55:1209-1218.

350 Dhodapkar MV, Steinman RM, Krasovsky J, Munz C, Bhardwaj N: Antigen-specific inhibition of effector $\mathrm{T}$ cell function in humans after injection of immature dendritic cells. J Exp Med 2001;193:233-238.

351 Jackson MR, Song ES, Yang Y, Peterson PA: Empty and peptide-containing conformers of class I major histocompatibility complex molecules expressed in Drosophila melanogaster cells. Proc Natl Acad Sci USA 1992;89:12117-12121.

-352 Cai Z, Brunmark A, Jackson MR, Loh D, Peterson PA, Sprent J: Transfected Drosophila cells as a probe for defining the minimal requirements for stimulating unprimed CD8+ T cells. Proc Natl Acad Sci USA 1996;93:14736-14741.
353 Mitchell MS, Darrah D, Yeung D, Halpern S, Wallace A, Voland J, Jones V, Kan-Mitchell J: Phase I trial of adoptive immunotherapy with cytolytic T lymphocytes immunized against a tyrosinase epitope. J Clin Oncol 2002;20:1075-1086.

354 Latouche JB, Sadelain M: Induction of human cytotoxic $\mathrm{T}$ lymphocytes by artificial antigen-presenting cells. Nat Biotechnol 2000;18:405-409.

355 Papanicolaou GA, Latouche JB, Tan C, Dupont J, Stiles J, Pamer EG, Sadelain M: Rapid expansion of cytomegalovirus-specific cytotoxic T lymphocytes by artificial antigen-presenting cells expressing a single HLA allele. Blood 2003;102:2498-2505.

356 Maus MV, Thomas AK, Leonard DG, Allman D, Addya K, Schlienger K, Riley JL, June $\mathrm{CH}$ : Ex vivo expansion of polyclonal and antigen-specific cytotoxic $\mathrm{T}$ lymphocytes by artificial APCs expressing ligands for the T-cell receptor, CD28 and 4-1BB. Nat Biotechnol 2002;20:143-148.

357 Thomas AK, Maus MV, Shalaby WS, June CH, Riley JL: A cell-based artificial antigen-presenting cell coated with anti-CD3 and CD28 antibodies enables rapid expansion and long-term growth of CD4 T lymphocytes. Clin Immunol 2002;105:259272.

358 Obermann S, Petrykowska S, Manns MP, Korangy F, Greten TF: Peptide-beta2microglobulin-major histocompatibility complex expressing cells are potent antigen-presenting cells that can generate specific T cells. Immunology 2007;122:90-97.

359 Kober J, Leitner J, Klauser C, Woitek R, Majdic O, Stockl J, Herndler-Brandstetter D, Grubeck-Loebenstein B, Reipert BM, Pickl WF, Pfistershammer K, Steinberger P: The capacity of the TNF family members 4-1BBL, OX40L, CD70, GITRL, CD30L and LIGHT to costimulate human T cells. Eur J Immunol 2008;38:2678-2688. 